\title{
An Overview on the Preparation, Characterization and Properties of Electrodeposited-Metal Matrix Nanocomposites
}

\author{
Singh VB* and Singh DK \\ Centre of Advanced Studies, Department Of Chemistry, Banaras Hindu University, India
}

Received: January 03, 2014; Accepted: October 09, 2014; Published: December 16, 2014

*Corresponding author: Singh VB, Centre of Advanced Studies, Department of Chemistry, Banaras Hindu University, Varanasi 221005, UP, India, Tel: 91-542-670-1606; Fax: 91-542-236-8127; E-mail: vijaybs@bhu.ac.in

\begin{abstract}
Several routes are available for the preparation of meta matrix nanocomposites. A variety of metal matrix nanocomposite materials with unique properties containing large range of diverse reinforcement have been prepared by various techniques characterized and utilized in many applications ranging from photo catalysis, photovoltaic cells, photoelectrochromic displays and lightemitting devices to sensors. In this review, we highlight the results of studies that have been obtained for metal matrix nanocomposites by electrodeposition which covers especially recent developments, variation in the physical and mechanical properties and their correlations with particle size and content of reinforcing particles. Many factors such as characteristics of matrix metal and particles itself along with other bath and deposition variables are found to influence the codeposition process, which led to some understanding of the mechanism. Models to predict the codeposition rate have been developed, but are only partly successful.
\end{abstract}

Keywords: Electro deposition; Metal matrix nanocomposites; XRD; Hardness; Electrical resistivity

\section{Introduction}

There is continuous effort by researcher in exploring alternatives to conventional materials and advances in materials performance which makes temptation in the development of composite systems. Nanocomposites are commonly known as materials consisting of two or more dissimilar materials with well defined interfaces, where at least one of the materials being nano structured in one, two, or three dimensions. Generally, one material forms a continuous matrix while the other provides the reinforcement. The two materials must be chemically inert with respect to each other so no interaction occurs upon heating until one of the components melts; an exception to this condition is a small degree of inter diffusion at the reinforcement-matrix interface to increase bonding. Co-deposition of particles in a metallic matrix enables the production of a large range of composite materials with unique properties. Metal-matrix nanocomposites are becoming commercially viable engineering materials that provide significant advantages over traditional monolithic alloys. In metal matrix nanocomposites, metal act as matrix i.e. continuous phase and second phase can be reinforcing materials e.g. oxides, carbides, nitrides etc. of various metal or alloys $\mathrm{Si}, \mathrm{Al}, \mathrm{Ti}, \mathrm{Zr}, \mathrm{W}$, B etc. Coatings of nanocomposite materials are used for protection of the automotive parts which are subject to corrosive environments $[1,2]$. Recently, these coatings have been considered due to their enhanced mechanical [3-5] magnetic [6] elevated temperature [7] optical [8,9] and excellent catalytic properties [10] metal matrix nanocomposites have considerable applications in aerospace, automotive and military industries due to their high mechanical properties and good physical behaviour including light weight, electrical and thermal conductivity [11] - The abrasion and corrosion resistance of components can be greatly increased by protective coatings and this is a growing industry of considerable economic importance [12]. Keeping above in view a broader aspect of metal matrix nanocomposites has been considered and discussed in this communication.

\section{General Methods of Preparation}

A number of processes are used for the preparation of composite materials depending on the required properties and choice of material system. Some of these are mentioned here such as $\mathrm{Al}-\mathrm{SiC}, \mathrm{Al}-\mathrm{Al}_{2} \mathrm{O}_{3}, \mathrm{Mg}-\mathrm{SiC}, \mathrm{Mg}-\mathrm{Al}_{2} \mathrm{O}_{3}$ of high specific strength , stiffness, temperature resistance, low thermal expansion coefficient, wear resistance and thermal conductivity are prepared by fusion infiltration, extrusion, forging, gravity and die casting while $\mathrm{PbC}$ and $\mathrm{Pb}-\mathrm{Al}_{2} \mathrm{O}_{3}$ for high stiffness and creep resistance are prepared by fusion infiltration only [13]. Cu-W for burn up resistance and $\mathrm{Pb}-\mathrm{C}$ and Brass-Teflon for load carrying capacity and wear resistance are prepared by powder metallurgy and infiltration. Similarly Equal Channel Angular Pressing (ECAP) for $\mathrm{Al}-\mathrm{Al}_{2} \mathrm{O}_{3}$, High Pressure Torsion (HPT) for $\mathrm{Cu}$-Fe composite, Hot pressing for $\mathrm{Cu}-\mathrm{Al}_{2} \mathrm{O}_{3}$ composite, hot extrusion for $\mathrm{Mg}-\mathrm{Al}_{2} \mathrm{O}_{3}$, Sintering for $\mathrm{Cu}-\mathrm{MgO}$, Microwave sintering for $\mathrm{Co}-\mathrm{WC}$, Plasma spraying for Al-CNT, High velocity oxyfuel spraying (HVOS) for $\mathrm{Ni}-\mathrm{Al}_{2} \mathrm{O}_{3}$, Cold spraying for Co-WC. Some other techniques such as spark plasma sintering, sol-gel and electrodeposition are also available for the preparation of metal matrix nanocomposites. 


\section{Electrolytic preparation: A novel approach}

Among all the techniques mentioned above, electrodeposition is the "one step-bottom up" approach for the preparation of metal matrix nanocomposites from electroactive species that can be reduced at the cathode. This is a most conventional technique and is used vastly due to its certain advantages over other competing technologies since it has the advantages of uniform deposition on complex shaped substrates, low cost, good reproducibility, easy control, being low energy process, and can be scaled down to the deposition of a few atoms or up to large dimensions near room temperature. Electrodeposition of metal matrix nanocomposite is the process in which micron or nano sized particles suspended in the electrolytic bath are codeposited in the growing metal layer with an applied current or potential used to deposit a film of metal or alloy by the reduction of metallic ions onto a conductive substrate. With the trend towards miniaturization, electrodeposition has established itself as the manufacturing technology of choice [14]. Electrodeposition has been used for the preparation of thin films of ferroelectric [15], piezoelectric [16], magnetic materials [17] superconductors [18] and semiconductors [19]. The interest in electrodeposition [20] for biomedical applications stems from a variety of reasons, such as the possibility of deposition of stoichiometric, high-purity material to a degree not easily achievable by other processing techniques and the possibility of forming coatings and bodies of complex shape. Electrodepositions are especially attractive for the design of solid-oxide fuel cells [21], solar cells, electrochromic devices [22], microelectronic devices, fiberreinforced composites and batteries [19]. Protective coatings and electrode materials were deposited via electrodeposition [23]. Electrolytic $\mathrm{TiO}_{2}, \mathrm{RuO}_{2}, \mathrm{SnO}_{2}, \mathrm{Nb}_{2} \mathrm{O}_{5}$, and composite films are of considerable interest for fabrication of dimensionally stable anodes, supercapacitors, and for other electrochemical and catalytic applications.

\section{Techniques for electrodeposition}

In general Direct Current (DC), such as either in the form of constant current or in the form of interrupted DC is used in the plating. Superimposition of Alternating Current (AC) on DC in the form of asymmetrical, pulse, symmetrical and periodic reverse current is also used in the electrodeposition. In the simplest case of DC electrodeposition a power source in the form of a battery or rectifier which converts AC electricity to regulated low voltage DC is providing the necessary current. This type of circuit arrangement directs electrons from the power supply (rectifier) to the cathode (the object to be plated). In its rudimentary stage, batteries have been used to carry out the process, which later on got augmented to the direct current. In its simplest form, pulse plating is carried out by interruption of DC during electrodeposition. Alternating current has a marked influence on many electrochemical reactions and has been established as suitable alternative technique to the conventional plating by direct current. It facilitates the anodic dissolution of certain metals (manganese, nickel, platinum, chromium etc), normally retarded by passivation. This affects the structure and properties of the deposits by reducing porosity and increasing brightness. Asymmetric AC deposition is the superimposition of $\mathrm{AC}$ on $\mathrm{DC}$ with the peak voltage of the AC being larger than that of the DC voltage so that periodic reversal of polarity takes place. A detail on the concept of pulse and pulse reverse plating has been reviewed by Chandrasekaran and Puspavanam [24]. The experimental set-up used for carrying out the electrodeposition and cathodic polarization measurement in our laboratory has been illustrated in Figures $1 \mathrm{a} \& 1 \mathrm{~b}$ respectively.

\section{Plating variables}

The codeposition of particulates within an electroplating process is an attractive procedure to produce improved materials for technological applications [25]. The principal parameters acting on the composite electrodeposition process are the compositions of the electrolytic bath, the presence of additives, the $\mathrm{pH}$ value, the temperature [26-29], the induced hydrodynamic conditions, the imposed current conditions [30] and of course the characteristics of the reinforcing particles size [31], conductivity [32] hydrophilicity/hydrophobicity [33]

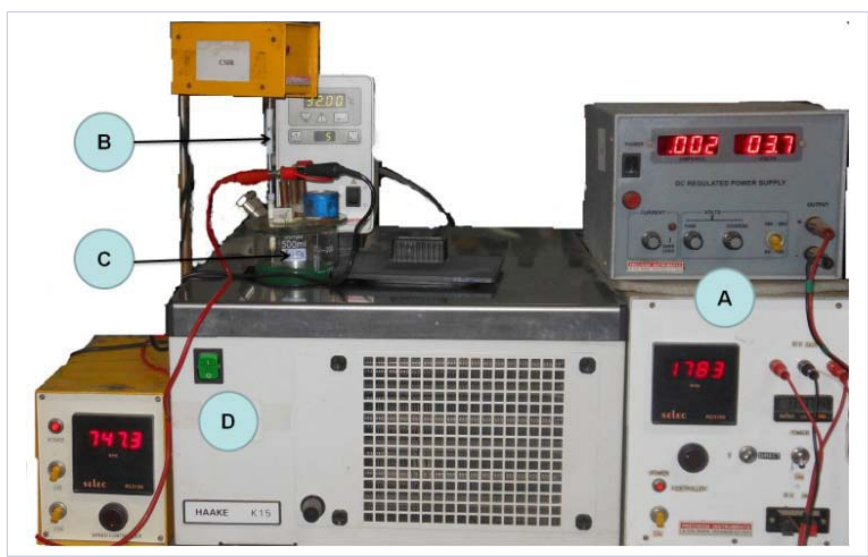

Figure 1a: Experimental set up for Electrodeposition (A) Regulated DC power supply (B) Stirrer (C) Electrolysis cell consisting of two nickel anodes and a copper cathode and (D) a thermostat to maintain the constant bath temperature.

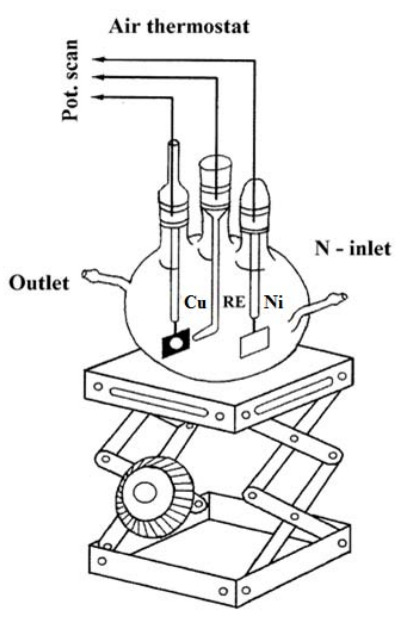

Figure 1b: Electrochemical set up for polarization studies. 
and surface charge [26,34]. The residence time of a particle, the velocities of the particle in the vicinity of the electrode and the effect of moving particles on stationary particles in contact with the electrode all play a role in the codeposition of the particles. It has been experimentally established that among all the deposition variables, current density plays most important role in producing nanocomposite, the number of nuclei increases linearly with time after the induction period and before saturation conditions are achieved. The saturation value depends on the operating conditions (mainly overvoltage, concentration of electroactive species); the deposits obtained at low current density consist of a small number of nuclei, with increasing current density the number of nuclei increases thus producing nanocrystalline deposits. The nanocrystallinity has been recognised to be obtainable with the systems associated with low exchange current density at overvoltage close to the end of the Tafel region. The exchange current density is actually the main reason for grain growth, also driving the growth of the larger grains at the expense of smaller ones [35]. Usually the deposits obtained from simple salt solutions presents a small number of isolated nuclei which grow into coarse crystallites while complexing in otherwise identical baths can give rise to the formations of nanocrystalline deposits. It is important to adjust the plating variables in order to control the properties of the produced composite coatings that depend on the amount of incorporated particles and their distribution.

\section{Mechanisms and models of particle codeposition in metallic matrix}

Several theoretical models have been proposed to describe the codeposition phenomenon and mechanism underlying particle incorporation in a metal matrix. However, the mechanism is not fully understood and the mathematical model to predict the amount of codeposited particles is verified only for few systems and in controlled conditions. The equations cannot take into account all the variables of the process and therefore have only been developed for particular experimental conditions.

The first attempt to explain electrochemical codeposition was made by Whithers [36]. He proposed that the particles with a positive surface charge are drawn to the cathode by electrophoresis. Williams and Martin [37] suggested that the particles are also transported to the cathode by the agitation of the bath and are mechanically entrapped by the growing metal layer Brandes et al. [38] rejected the idea of mechanical entrapment. They suggested that there is some attractive force holding the particles at the cathode long enough to be incorporated by the growing metal layer. Saifullin et al. [39] were the first to present a model to calculate the weight percent of incorporated particles. This model was based on mechanical entrapment only and has to be rejected. Three years later Bazard et al. [40] proposed that the particles collide with the cathode surface due to the bath agitation and that the particles should stay at the cathode surface a certain time to become occluded. They developed a simple equation to calculate the weight percent of embedded particles.

The first quantitative model of electrolytic codeposition of MMCs was proposed by Guglielmi [41] which was based on a two-step codeposition mechanism. The proposed steps were

(1) adsorption of a layer of loosely adsorbed particles and then

(2) a strong adsorption of the particles onto the electrode.

The loose adsorption coverage, a ratio of the area covered by loosely adsorbed particles to the total electrode area, was expressed in terms of the concentration of suspended particles using the classical Langmuir adsorption isotherm. For the strong adsorption rate, the volume of particles strongly adsorbed was given by a Tafel-type exponential relationship at high over potentials that depended on kinetic constants. The volume of metal electrodeposited was obtained by Faraday's law. Thus, the volume fraction of incorporated particles was then formulated as a function of the bulk concentration and the electrode over potential. From this model the volume fraction of incorporated particles, $\alpha$, can be mathematically expressed by:

$$
\frac{\alpha^{\prime}}{1-\alpha^{\prime}}=\frac{z F \rho_{m} V_{o}}{M_{m} i_{o}} e^{(\mathrm{B}-A) \eta} \frac{k C_{p, b}}{1+k C_{p, b}}
$$

Where $M_{m}$ and $\rho_{\mathrm{m}}$ are the atomic weight and the density of electrodeposited metal respectively, $i_{0}$ the exchanging current density, $z$ the valence of the electrodeposited metal, $F$ the Faraday constant, $\eta$ the electrode reaction over potential, $C_{p, b}$ the particle concentration in the bulk electrolyte and $k$ the Langmuir isotherm constant, mainly determined by the intensity of interaction between particles and cathode. The parameters $V_{0}$ and $B$ are related to particle deposition, and both play a symmetrical role with the parameters $i_{0}$ and A related to metal deposition. The adsorption of metals ions on the particles surface forming an ionic cloud was subsequently considered by Foster et al. [42] taking into account the $\zeta$-potential and electrophoretic forces. The particle deposition rate is again defined as a Langmuir adsorption isotherm, where the measure of the particle cathode interaction $k$ depends on:

- The electrostatic interaction, which is determined by the charge adsorbed on the particles and the potential field at the cathode.

- The physical bond, which depends on the rate at which metal is deposited, that is the current density.

- Mechanical factors, like the particle properties and the agitation rate.

This model was adopted for many years but the amount of embedded particles was meant to be dependent only on the particles concentration and on the current density. Valdes [43] used the wealth of knowledge that existed on the deposition of Brownian particles on surfaces and applied it to the field of electrolytic codeposition. The complex and often ill-understood correlations between the transport of ions and the transport of particles in a plating bath make it a formidable task. Apart from the usual Brownian diffusion and hydrodynamic convection, Valdes also considered electromigration (electrophoretic transport) and diffusion migration among the transport 
mechanisms, bringing particles from the bulk of the suspension to the interface. Electrophoretic and diffusiophoretic motions are interfacially driven transport mechanisms caused by the polarization of the double layer surrounding a charged particle in response to an electrical field and a concentration gradient. Electrophoretic transport is determined by the sign and value of the zeta potential of the particle. Diffusiophoresis, on the other hand, drives particles towards regions of higher electrolyte concentration irrespective of the sign of surface charge of the particle. Valdes models the electro-deposition of Brownian particles on a RDE using three different boundary conditions: the Perfect Sink (SINK) model, the Surface Force Boundary Layer Approximation (SFBLA) and the Electrode-Ion-Particle-Electron Transfer (EIPET) model.

- The perfect sink model is the easiest. It assumes that the attraction forces dominate, so that particles that make contact with the electrode are irreversibly captured. This boundary condition leads to a codeposition model that is mass-transport controlled.

- In the SFBLA approach, the interaction potential near the electrode is composed of the traditional DerjaguinLandau-Verwey-Overbeek (DLVO) forces and the electrophoretic and diffusiophoretic contributions.

- In the EIPET boundary condition, the electrochemical reduction of electro-active ions adsorbed on the particle provides the essential surface binding interaction which is responsible for particle deposition on the electrode surface.

Eng [44] extended Valdes' modelling approach to a Rotating Cylinder Electrode (RCE). She assumed that the transport of particles by convection can be neglected. The influence of convection is taken into account by the thickness of the diffusion layer. It is assumed that the diffusion layer thickness varies with rotation speed in accordance with an empirical correlation that was established experimentally. Three kinetic models for the particle codeposition were considered: the perfect sink model, the surface force boundary layer approximation model and the Modified Electrode-Ion-Particle Electron Transfer (MEIPET) model. Her model with perfect sink kinetics predicts that the flux of particles is independent of rotation speed. This is due to the fact that the flux of particles and metal depends on the rotation speed in an identical way. The SFBLA and MEIPET boundary conditions yield a codeposition rate that decreases with increasing rotation speed.

To overcome the shortcoming in the Guglielmi's model; Celis et al. [45] and later Fransaer et al. [46] developed a model to non-Brownian particles (particles diameter $<1 \mu \mathrm{m}$ ) that took into account also the hydrodynamic effect and the particles characteristics. The basic assumption of this model is that all particles are surrounded by a cloud of adsorbed species, mainly metal ions, and can be incorporated into the metal matrix only if an efficient part of these chemical species is reduced at the same time with the metal ions on the cathode. Moreover, the model considers spherical particles and the current efficiency is $100 \%$ which is based on the important influence of the electrolyte stirring. The model consists of five consecutive steps as

- Formation of ionic clouds on the particles;

- Convection towards the cathode surface;

- Diffusion through a hydrodynamic boundary layer;

- Diffusion through a concentration boundary layer;

- Adsorption at the cathode where particles are entrapped within the metal deposit by the reduction of the ionic cloud.

This model has been used successfully on the qualitative explanation of experimental data for Zn-polystyrene composite depositions. However, the particle electrode interaction forces and their relative importance remained in question. Hwang and Hwang [47] extended an improvement on Guglielmi's model by adopting it to the mechanism put forward by Celis et al. [45]. For three current density ranges the particle deposition rate is determined by the electrode reactions for ions adsorbed on the particles whose rates are determined by kinetic and/ or diffusion parameters. A diffusion layer and concentration profile equivalent to that at an electrode are thought to develop at the particle surface. Since, Co-SiC composite deposition was experimentally investigated, the starting point is the reduction of $\mathrm{H}^{+}$and $\mathrm{Co}^{2+}$ adsorbed on the particles. Three different current density ranges for the reduction of these ions are distinguished:

- Low current density where only $\mathrm{H}^{+}$ions are reduced

- Intermediate current density, where the $\mathrm{H}^{+}$reduction rate has reached its limiting value and also $\mathrm{Co}^{2+}$ is reduced.

- High current where for both ions the reduction rate is at its limiting value.

Later Vereecken et al. [48] proposed another model which took into account the particles kinetics and residence time at the electrode surface and suggested the transport of particles to the surface is controlled by convective-diffusion. The influence of particle gravitational force and hydrodynamics is accounted for various current densities but is valid only when the particle size is smaller than the diffusion layer thickness. Recently Lee and Talbot [49] proposed a model to predict the amount of nanoparticle incorporation in a kinetically as well as in the mass transfer limited region of the electrochemical deposition. The validity of the various theoretical models, underlying particle incorporation in a metal matrix, still requires much attention, since the electrochemical co-deposition is still not fully understood $[30,50]$. Currently the models used to explain the entrapment of the particles are confined to specific conditions, therefore primary empirical laboratory trials remain important and will require special attention to interactive variables and operating electrolysis parameters. Subsequent models which have been formulated time to time did not succeed to provide a general approach to the codeposition of inert particles into metallic coatings even if much more factors have been taken into consideration. However, the flexibility and the reliability of each model to describe the behaviour of a wide range of metallic 
coatings and particle types still require validation. Often the mathematical relationship is strictly related to the experimental set-up and in all the models available so far the effect of the particles codeposition on the deposit electrocrystallization has not been considered.

\section{Cathodic polarization study}

The polarization behaviour of metal plays an important role in cathodic deposition which controls the process of deposition and also influences the electrocrystallization behaviour of metals which in turn governs the micro and crystallographic structures of the grown film. The charge transfer controlled electrodeposition gives rise to large grains with generally well defined crystallites shapes. Cathodic polarization behaviour of the metal and nanocomposite was studied in our laboratory to understand the electrochemical aspect.

Figure 2 depicts the variation of current density with cathode potential for nickel electrodeposition from nickel acetate-NMF bath in the absence and presence of $10 \mathrm{gL}^{-1}$ of $\mathrm{SiC}, \mathrm{TiC}_{(\mathrm{nm})}, \mathrm{WC}$, $\mathrm{B}_{4} \mathrm{C}$ and $\mathrm{Al}_{4} \mathrm{C}_{3}$ particles. The polarization curves for $\mathrm{Ni}$ and $\mathrm{Ni}$ in the presence of different particles were found similar in nature. It is observed from the figure that with successive increase in the potential in the cathodic direction, current remains almost nearly the same and above $200 \mathrm{mV}$ it shows mild tendency to increase with increasing potential but as the potential approached $\sim 500$ $\mathrm{mV}$ it started increasing and a sharp increase was observed above $700 \mathrm{mV}$. It is also noticed that in the presence of particles the curve shifted to a less negative potential even if the nature is alike. This reveals depolarization in the presence of the particles. It seems that particles can decrease the cathode polarization due to ionic clouds created around particles. Watson [51] found that SiC particles can impose a positive displacement of the polarization curve for nickel reduction. It was attributed to the increase in the adsorption of $\mathrm{H}^{+}$and $\mathrm{Ni}^{+}$intermediate near the electrode which can participate in the cathodic reaction and showed a rapid increase in current at particular cathode potential of $-580 \mathrm{mV}$.

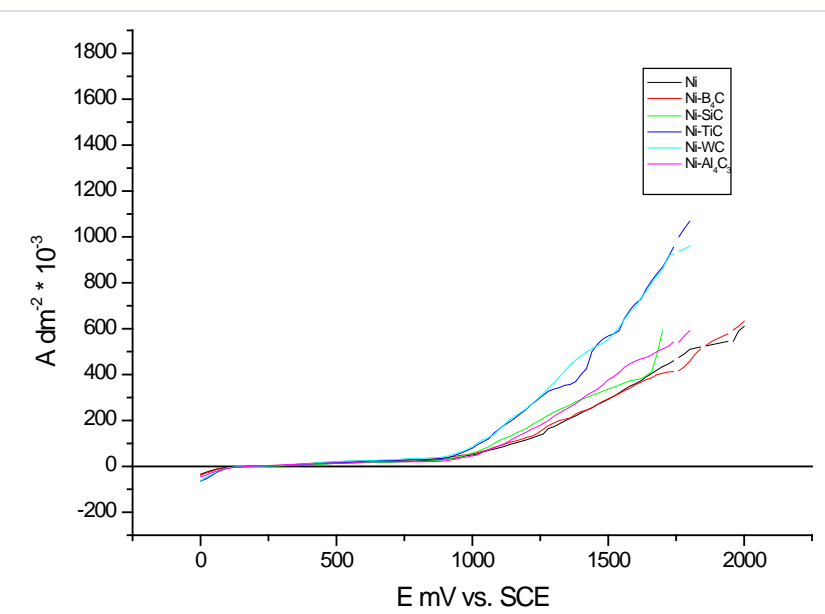

Figure 2: The polarizarion curve for nickel with and without carbide particles (Nickel acetate $200 \mathrm{~g} / \mathrm{L}$, boric acid $35 \mathrm{~g} / \mathrm{L}$, carbide $10 \mathrm{~g} / \mathrm{L}$, Stirring rate $400 \mathrm{rpm}$, Temperature $55^{\circ} \mathrm{C}$ ).
Similar depolarization behavior has also been reported [52] and the observed depolarization was attributed to the enhanced mass transfer to some extent due to adsorbed $\mathrm{Ni}^{2+}$ ions on the surface of $\mathrm{ZrO}_{2}$ particles. In another paper on cathodic polarization study for copper deposition with and without $\mathrm{ZrB}_{2}$ particles, it has been observed that the cathode current is decreased by the addition of $\mathrm{ZrB}_{2}$ particles at constant overpotential. This polarizing effect is probably due to the inhibition of the cathode surface by the particles, which leads to the raising of the local cathode current density; such an observation has been earlier reported by many researchers [53-55].

\section{Electrodeposition of metal matrix nanocomposite coatings}

The first paper on the electrodeposition of metal matrix composite coatings described the copper-graphite system for self-lubricating surfaces in car engines [56] but the development of hardened films started only in the 1960s [57]. The wear properties of $\mathrm{Ni}-\mathrm{SiC}$ as well as $\mathrm{Ni}-\mathrm{Al}_{2} \mathrm{O}_{3}$ composite coatings were studied by many research groups as these coatings could be a good candidate to substitute the hard chromium coatings [58-60]. It has been found that the codeposited content of $\mathrm{Al}_{2} \mathrm{O}_{3}$ particles in nickel matrix increases by increasing the particles content in the galvanic bath with a decreasing rate and reaches a plateau that depends on the bath, temperature and current condition [61]. This behaviour was confirmed by other studies for a wide range of codeposition systems [62-64]. Different particles / sizes, current conditions and different electroplating baths have been employed and experimented and it was observed that the amount of particles codeposited varied for different systems. The wear resistance of the coatings increases by the addition of micro or submicron particles due to the high amount of incorporated particles and their high intrinsic hardness. On the other hand, the presence of a high amount of relatively big particles could worsen the corrosion properties of the coating due to the presence of voids between the particles and the metal matrix, which are the preferred path of propagation for the corrosive solutions.

There exists substantial reported work on the preparation of composite coatings via electrodeposition but here attention has been focused on only metal matrix based nanocomposite coating using micro- and nano-sized particles that arouse technological interest to the production with improved and well-controlled properties. Literature review reveals that electrodeposition of MMCs involves numerous matrix, reinforcement, bath variables and deposition variables and the resulting composites show different characteristics which make difficult to describe the details of studies and findings systematically; therefore it has been summarized in tabular form (Table 1) which include main features of the electrodeposited composite systems.

Coatings with nickel matrices are the most abundant among electrolytically produced composite coatings and electrodeposition of nickel composite coatings containing hard ceramic particles has been discussed frequently in the literature $[1,54,82]$. A variety of particles have been successfully incorporated into metallic electrodeposits. These include oxides such as $\mathrm{Al}_{2} \mathrm{O}_{3}, \mathrm{ZrO}_{2}, \mathrm{TiO}_{2}, \mathrm{Cr}_{2} \mathrm{O}_{3}, \mathrm{SiO}_{2}, \mathrm{CeO}_{2}, \mathrm{RuO}_{2}, \mathrm{IrO}_{2}, \mathrm{Fe}_{2} \mathrm{O}_{3}, \mathrm{MoO}_{2}$ 
or carbides like $\mathrm{SiC}, \mathrm{WC}, \mathrm{TiC}, \mathrm{B}_{4} \mathrm{C}$ or nitrides like $\mathrm{Si}_{3} \mathrm{~N}_{4}$ and $\mathrm{BN}$ to self lubricating particles such as $\mathrm{MoS}_{2}$, diamond, graphene, graphite, fluoro graphite and PTFE etc; and the salient features of these investigations are listed in table 2 . In addition to these, various nitrides [83] ( $\mathrm{SiN}, \mathrm{BN}, \mathrm{WN})$, oxides [84] $\left(\mathrm{ZrO}_{2}, \mathrm{SiO}_{2}, \mathrm{Al}_{2} \mathrm{O}_{3^{\prime}}\right.$ $\mathrm{TiO}_{2}$ ) and carbides [85-88] ( $\mathrm{SiC}, \mathrm{TiC}, \mathrm{B}_{4} \mathrm{C}, \mathrm{WC}$ and $\mathrm{Al}_{4} \mathrm{C}_{3}$ ) have been used as particulate to reinforce nickel and $\mathrm{Ni}$ - $\mathrm{Fe}$ matrix in our laboratory and sound composite coatings have been achieved by electrodeposition method using various organic solvents like NMF, DMF, ethanolamine and ethylene glycol. The composites were subjected to thorough characterization for their composition, morphology and crystallographic structure and evaluation of micro hardness and electrical resistivity was done.

\section{Electrodeposition of $\mathrm{Ni}$-Carbide composite coating}

By convention, the term carbide is only applied to those compounds formed by carbon and other elements of lower or about equal electro negativity. The carbides, as defined above, can be classified in four general categories which are commonly identified as: Interstitial, covalent, Intermediate and Salt like carbides. These carbides are hard and wear resistant, have high melting points and are chemically inert. Refractory carbides are

Table 1:

\begin{tabular}{|c|c|c|c|c|}
\hline Matrix & Reinforcement & Additives & Remarks & Reference \\
\hline Co & $\mathrm{TiO}_{2}$ & $\begin{array}{l}\mathrm{NaCl} \\
\mathrm{Na}_{2} \mathrm{SO}_{4} \cdot 10 \mathrm{H}_{2} \mathrm{O} \\
\mathrm{C}_{6} \mathrm{H}_{15} \mathrm{NO}_{3}\end{array}$ & $\begin{array}{l}\text { Influence of film thickness on microstructure and functional } \\
\text { properties of the nanocomposite films with an average } \\
\text { thickness comprised in the }(0.07-0.63) \mu \mathrm{m} \text { range, applications } \\
\text { in spintronics. }\end{array}$ & {$[65]$} \\
\hline Co & BN (h) & - & $\begin{array}{l}\text { Mechanical properties improved i.e. higher hardness, lower } \\
\text { friction coefficient and high wear resistance }\end{array}$ & [66] \\
\hline Co & Diamond & - & Incorporation of diamond in matrix causes deterioration. & [67] \\
\hline $\mathrm{Cr}$ & $\mathrm{SiC}$ & - & $\begin{array}{l}\text { Studied the effect of the pulse-current frequency on } \\
\text { morphology and hardness }\end{array}$ & [68] \\
\hline $\mathrm{Cr}$ & WC & $\begin{array}{l}\text { Trivalent } \mathrm{Cr} \text { salt } \\
\text { with additive }\end{array}$ & $\begin{array}{l}\text { Showed better hardness, corrosion resistance and wear } \\
\text { resistance performance compared with the chromium-free } \\
\text { deposit }\end{array}$ & [69] \\
\hline $\mathrm{Cu}$ & $\mathrm{SiO}_{2}$ & $\mathrm{C}_{6} \mathrm{H}_{12} \mathrm{O}_{6}$ & Effects of nano- $\mathrm{SiO}_{2}$ and $\mathrm{C}_{6} \mathrm{H}_{12} \mathrm{O}_{6}$ on coatings & [70] \\
\hline $\mathrm{Cu}$ & $\mathrm{SiO}_{2}$ & $\begin{array}{l}\text { Cetyl trimethyl } \\
\text { ammonium } \\
\text { bromide (CTAB) }\end{array}$ & $\begin{array}{l}\text { CTAB stabilizes } \mathrm{SiO}_{2} \text { suspension, promotes the nanoparticles } \\
\text { incorporation in the matrix and improves the deposit } \\
\text { morphology and structure. Consequently a higher corrosion } \\
\text { resistance }\end{array}$ & [71] \\
\hline $\mathrm{Cu}$ & $\mathrm{Al}_{2} \mathrm{O}_{3}$ & - & $\begin{array}{l}3.5 \text { vol. } \% \mathrm{Al}_{2} \mathrm{O}_{3} \text { in composite causes grain refinement of metal } \\
\text { matrix and } 25 \% \text { higher hardness than pure } \mathrm{Cu} \text {, can improve } \\
\text { reliability of MEMS devices. }\end{array}$ & [72] \\
\hline $\mathrm{Fe}-\mathrm{Ni}-\mathrm{Cr}$ & $\mathrm{SiC}$ & Carboxylate-Urea & $\begin{array}{l}\text { Hydrogen evolution reaction (HER) could be inhibited by } \\
\text { carboxylate-urea system, which increases } \mathrm{SiC}, \mathrm{Cr} \text { contents and } \\
\text { the thickness of the coatings. }\end{array}$ & [73] \\
\hline PPy & Gold Nanoparticless & - & $\begin{array}{l}\text { Showed excellent sensitivity, selectivity, reproducibility and } \\
\text { stability properties and acted as electro-chemical sensor for } \\
\text { hydroxylamine (HA) }\end{array}$ & [74] \\
\hline Zn & $\mathrm{TiO}_{2}$ & - & $\begin{array}{l}\text { Influence of substrate steel and titanium on annealing } \\
\text { temperature of composites and texture coefficient, crystallite } \\
\text { size }\end{array}$ & [75] \\
\hline $\mathrm{Zn}$ & $\mathrm{TiO}_{2}$ & - & $\mathrm{TiO}_{2}$ has a strong influence on the deposit surface morphology & [76] \\
\hline $\mathrm{Zn}$ & $\mathrm{TiO}_{2}$ & - & $\begin{array}{l}\text { The nanocomposites prepared with the highest } \mathrm{i}_{\mathrm{a}} \text { value }(19 \mathrm{~mA} \\
\left.\mathrm{cm}^{-2}\right) \text {, exhibit the highest values for the zinc average crystallite } \\
\text { size and } \mathrm{TiO}_{2} \text { content. }\end{array}$ & [77] \\
\hline $\mathrm{Zn}$ & $\mathrm{SiO}_{2}$ & $\begin{array}{l}\text { Surfactant } N, N- \\
\text { dimethyldodecyl- } \\
\text { amine }\end{array}$ & $\begin{array}{l}\text { Wt.\% of larger particles }(2 \mu \mathrm{m}) \text { was higher than that of smaller } \\
\text { ones in the deposits }(20 \mathrm{~nm}) \text { under similar experimental } \\
\text { conditions. }\end{array}$ & [78] \\
\hline Zn & $\mathrm{V}_{2} \mathrm{O}_{5}$ & - & Higher corrosion resistance & [79] \\
\hline Zn & $\mathrm{MoS}_{2}$ & $\begin{array}{l}\text { Sodium dodecyl } \\
\text { sulfate (SDS) }\end{array}$ & $\begin{array}{l}\mathrm{MoS}_{2} \text { changed the microstructure and crystallographic } \\
\text { structure of the deposits and enhanced corrosion resistance of } \\
\text { coatings. }\end{array}$ & {$[80]$} \\
\hline $\mathrm{Zn}$ & $\mathrm{WS}_{2}$ and $\mathrm{ZrO}_{2}$ & SDS & $\begin{array}{l}\text { Uses zinc-sulfate chloride bath and sulphate bath, respectively. } \\
\text { Corrosion resistant coating, affect texture of Zn on mild steel }\end{array}$ & [81] \\
\hline
\end{tabular}


Table 2:

\begin{tabular}{|c|c|c|c|}
\hline Matrix & Reinforcement & Remarks & References \\
\hline \multirow{7}{*}{$\mathrm{Ni}$} & \multirow{7}{*}{$\mathrm{Al}_{2} \mathrm{O}_{3}$} & $\begin{array}{l}\text { - Effect of current density, particle concentration in the bath and particle size on the amount of particles } \\
\text { co-deposited. } \\
\text { - The amount of } \mathrm{Al}_{2} \mathrm{O}_{3} \text { co-deposited in the films increases with the particle concentration in the bath and } \\
\text { strongly depends on the current density and on particle size. }\end{array}$ & [89] \\
\hline & & $\begin{array}{l}\text { - Additives- SDS, saccharin and coumarin } \\
\text { - Manipulate the composite material properties by optimizing surfactants. } \\
\text { - Improved Hardness of composite. }\end{array}$ & [90] \\
\hline & & $\begin{array}{l}\text { - Uses } \mathrm{Al}_{2} \mathrm{O}_{3} \text { powder from three different sources and effect of different forms of alumina particles on the } \\
\text { microhardness and microstructure of the composite was studied. } \\
\text { - Combustion synthesized alumina particles show higher microhardness (550 HK). }\end{array}$ & [91] \\
\hline & & $\begin{array}{l}\text { - Uses rotating polyhedron cathode composed of eight pieces of copper foil fixed on the side faces of a } \\
\text { regular octagonal nylon prism } \\
\text { - Graded composite }\end{array}$ & [92] \\
\hline & & $\begin{array}{l}\text { - The influence of hydrodynamics and pulse plating parameters on the electrocodeposition. } \\
\text { - A maximum incorporation of } 12 \text { vol. \% of } 50 \mathrm{~nm} \gamma-\mathrm{Al}_{2} \mathrm{O}_{3} \text { particles in a nickel matrix was achieved using } \\
\text { an unsubmerged IJE system, while PP and PRP resulted in composites with particle contents up to } 11 \text { vol. } \\
\% \text { of } 13 \mathrm{~nm} \gamma-\mathrm{Al}_{2} \mathrm{O}_{3} \text { particles. }\end{array}$ & [61] \\
\hline & & $\begin{array}{l}\text { - Studied the effect of mechanical and ultrasound agitation on the properties. } \\
\text { - Ultrasound was found better in improving tribological properties. }\end{array}$ & [93] \\
\hline & & $\begin{array}{l}\text { - Effects of pulse parameters, i.e. duty cycle and frequency on the hardness and wear resistance of the } \\
\text { coatings. }\end{array}$ & [94] \\
\hline \multirow{4}{*}{$\mathrm{Ni}$} & \multirow{4}{*}{$\mathrm{ZrO}_{2}$} & - Improved hardness and tribocorrosion properties & [95] \\
\hline & & $\begin{array}{l}\text { - The microhardness and wear resistance of the coatings increase with increasing weight percentage of } \\
\text { particles content in the coating }\end{array}$ & [96] \\
\hline & & $\begin{array}{l}\text { - Deposited from Watts bath using direct current (DC), pulsed current (PC), and pulsed reverse current } \\
\text { (PRC) conditions. } \\
\text { - The PC and PRC deposition conditions resulted in more random/weak crystallographic texture } \\
\text { compared to DC deposition. }\end{array}$ & {$[97]$} \\
\hline & & $\begin{array}{l}\text { - sediment electrodeposition } \\
\text { - Studied the hardness, elastic modulus, residual stress, thermal expansion coefficient and thermal } \\
\text { conductivity of the coatings. }\end{array}$ & [98] \\
\hline \multirow{4}{*}{$\mathrm{Ni}$} & \multirow{4}{*}{$\mathrm{TiO}_{2}$} & $\begin{array}{l}\text { - Influence of current density, concentration of particles, effect of agitation and ultrasonic waves on } \\
\text { deposition. } \\
\text { - Optimal values of current density, concentration of particles, and agitation rate exist that maximum } \\
\text { percent of particles codeposited in the coating. }\end{array}$ & [99] \\
\hline & & $\begin{array}{l}\text { - Pulse electrodeposition } \\
\text { - Studied corrosion resistance and mechanical properties of coating for sintered Nd-Fe-B magnet. }\end{array}$ & {$[100]$} \\
\hline & & - Studied the microstructure, friction, and wear properties of the coatings. & {$[101]$} \\
\hline & & - Best photo response for the $\mathrm{Ni}^{-\mathrm{TiO}_{2}}$ films were obtained from a specific composition of the bath. & {$[102]$} \\
\hline \multirow[b]{2}{*}{$\mathrm{Ni}$} & \multirow[b]{2}{*}{$\mathrm{Cr}_{2} \mathrm{O}_{3}$} & $\begin{array}{l}\text { - The catalytic activity for ethanol oxidation of fabricated electrodes increases with increasing the volume } \\
\text { fraction percent }\left(\mathrm{V}_{\mathrm{f}} \%\right) \text { of } \mathrm{Cr}_{2} \mathrm{O}_{3} \text { in the deposited film up to } 7 \mathrm{~V}_{\mathrm{f}} \% \text {. }\end{array}$ & [103] \\
\hline & & $\begin{array}{l}\text { - Watts bath } \\
\text { - Incorporation of } \mathrm{Cr}_{2} \mathrm{O}_{3} \text { particles enhanced the microhardness, tribological behaviour and thermal } \\
\text { stability of the nano-composite. }\end{array}$ & [104] \\
\hline \multirow{2}{*}{$\mathrm{Ni}$} & \multirow{2}{*}{$\mathrm{SiO}_{2}$} & $\begin{array}{l}\text { - Studied the particle-electrode surface interaction during electrodeposition. } \\
\text { - Incorporation of hydrophobic particles in the matrix was found to be more than hydrophilic particles. }\end{array}$ & [105] \\
\hline & & - Good wear resistance in the running-in period, with increasing particle content in the plating solution. & [106] \\
\hline \multirow[t]{2}{*}{$\mathrm{Ni}$} & \multirow{2}{*}{$\mathrm{CeO}_{2}$} & $\begin{array}{l}\text { - Plating bath containing Ni and Ce ions with no oxide powder. } \\
\text { - Morphology of Ni-cerium oxide coatings varied based on the Ni:Ce ion ratio. }\end{array}$ & [107] \\
\hline & & - High temperature corrosion resistance. & [108] \\
\hline
\end{tabular}




\begin{tabular}{|c|c|c|c|}
\hline \multirow{2}{*}{$\mathrm{Ni}$} & \multirow{2}{*}{$\mathrm{RuO}_{2}$} & $\begin{array}{l}\text { - Three different baths namely Watts, Chloride and Thiosulfate were used, co-deposition from Watts baths } \\
\text { proved the most effective and co-deposition produces activated electrodes for hydrogen evolution. }\end{array}$ & [109] \\
\hline & & $\begin{array}{l}\text { - Studied the influence of deposition current density on the composition and on hydrogen evolution of } \\
\text { electrodeposited } \mathrm{Ni}+\mathrm{RuO}_{2}\end{array}$ & {$[110,111]$} \\
\hline $\mathrm{Ni}$ & $\mathrm{IrO}_{2}$ & $\begin{array}{l}\text { - Influence of deposition current density on the composition and on hydrogen evolution of } \\
\text { electrodeposited } \mathrm{Ni}+\mathrm{IrO}_{2}\end{array}$ & [111] \\
\hline $\mathrm{Ni}$ & $\mathrm{Fe}_{2} \mathrm{O}_{3}$ & $\begin{array}{l}\text { - Coating was applied onto ferritic stainless steel for intermediate temperature solid oxide fuel cell (SOFC) } \\
\text { interconnects application. }\end{array}$ & [112] \\
\hline $\mathrm{Ni}$ & $\mathrm{MoO}_{2}$ & $\begin{array}{l}\text { - Studied the effect of aging of the electrolyte on composite morphology, chemical composition, } \\
\text { polarization characteristics and "service life", tested for the hydrogen evolution reaction. }\end{array}$ & [113] J \\
\hline & \multirow{5}{*}{$\mathrm{Si}_{3} \mathrm{~N}_{4}$} & - Evaluated the microhardness, wear and corrosion properties. & [114] \\
\hline & & $\begin{array}{l}\text { - Studied the tensile super plasticity and found a maximum elongation of } 635 \% \text { at } 713 \mathrm{~K} \text { and a strain rate } \\
\text { of } 1 \times 10^{-2} \mathrm{~s}^{-1} \text {. } \\
\text { - Also noted significant amount of twinning and dislocations. }\end{array}$ & [115] \\
\hline $\mathrm{Ni}$ & & $\begin{array}{l}\text { - Evaluated the friction and wear properties while being lubricated with various oils using a ball-on-disk } \\
\text { sliding tester. }\end{array}$ & [116] \\
\hline & & $\begin{array}{l}\text { - Studied the structure, surface morphology and the microhardness of the composites and a correlation } \\
\text { between the particle content, cobalt content and structure was attempted }\end{array}$ & [117] \\
\hline & & $\begin{array}{l}\text { - Incorporation of particles increased the surface roughness of the matrix but did not influence its } \\
\text { structure. } \\
\text { - Microhardness increases on annealing. }\end{array}$ & [118] \\
\hline \multirow[b]{2}{*}{$\mathrm{Ni}$} & \multirow[b]{2}{*}{ BN } & $\begin{array}{l}\text { - Additive alkyl-dimethyl-benzyl-ammonium saccharinate. } \\
\text { - Improved hardness and corrosion resistance. }\end{array}$ & [119] \\
\hline & & $\begin{array}{l}\text { - In the first step a uniform film of BN was first electrophoretically deposited on an iron plate. } \\
\text { - and nickel was then electrodeposited in the second step onto the substrate covered with the film of BN. }\end{array}$ & [120] \\
\hline \multirow[t]{2}{*}{$\mathrm{Ni}$} & \multirow{2}{*}{$\mathrm{MoS}_{2}$} & $\begin{array}{l}\text { - The synergetic effects of graphite, } \mathrm{MoS}_{2} \text {, and metallic silver lubricants on the tribological characteristics } \\
\text { of composites were analyzed. } \\
\text { - The synergetic lubricating effect of molybdate (produced in the rubbing process at high temperatures) } \\
\text { iron oxide (transfer from disk material to the pin) and remaining graphite multiple-lubricants play an } \\
\text { important lubricating role during friction tests at a wide temperature range. }\end{array}$ & [121] \\
\hline & & $\begin{array}{l}\text { - Additives-ammonium lignosulfonate (ALS) and depramin-C (DC). } \\
\text { - Watts bath containing leveler, wetting agent and brightener by using a potentiostat. } \\
\text { - Addition of } \mathrm{MoS}_{2} \text {, decrease in temperature and increasing } \mathrm{pH} \text { decreases peak current density of HER } \\
\text { regardless of the surfactant used. On the other hand, the surfactants increased the peak current density. }\end{array}$ & [122] \\
\hline \multirow[t]{5}{*}{$\mathrm{Ni}$} & \multirow{5}{*}{ Diamond } & $\begin{array}{l}\text { - Studied the influence of plating solution, current density (d.c.), current frequency (pulse plating), plating } \\
\text { temperature, plating time, and stirring speed during plating processes. } \\
\text { - The microhardness and wear resistance increases with increasing diamond content while friction } \\
\text { coefficient decreases. }\end{array}$ & [123] \\
\hline & & $\begin{array}{l}\text { Potential structural materials for MEMS, higher diamond concentration renders composites more } \\
\text { compressively stressed }\end{array}$ & {$[124]$} \\
\hline & & $\begin{array}{l}\text { - Particles in bath cause the reduction potential of nickel to shift to more negatives and nickel deposition } \\
\text { has higher charge transfer resistance. } \\
\text { - Particles in composite coating provide better corrosion performance. }\end{array}$ & [125] \\
\hline & & $\begin{array}{l}\text { - Studied electrodeposition process, phase composition, structure, physicomechanical and corrosion- } \\
\text { electrochemical properties of composite. } \\
\text { - Coatings with enhanced resistance to wear and corrosion. }\end{array}$ & [126] \\
\hline & & - Results indicated that the metal incorporation effectively increased the graphitization of DLC films. & [127] \\
\hline $\mathrm{Ni}$ & Graphene & - The crystallite size, texture coefficients, corrosion resistance and hardness of coating was measured. & {$[128,129]$} \\
\hline \multirow{2}{*}{$\mathrm{Ni}$} & \multirow{2}{*}{ Graphite } & $\begin{array}{l}\text { - Uniform mass transport regime is essential to achieve a uniform distribution of particles over the entire } \\
\text { coated surface. }\end{array}$ & [130] \\
\hline & & - Influence of graphite content, load and rotating speed on the properties of friction and wear. & [131] \\
\hline $\mathrm{Ni}$ & Fluorographite & - Additive- Octyl phenyl polyoxyethylene glycol glycol. & [132] \\
\hline \multirow{2}{*}{$\mathrm{Ni}$} & \multirow{2}{*}{ PTFE } & $\begin{array}{l}\text { - Electrodeposition from deep eutectic solvent (DES). } \\
\text { - Ni-3.1wt.\% PTFE composite shows hydrophobic behavior with enhanced wear resistance. }\end{array}$ & [133] \\
\hline & & $\begin{array}{l}\text { - Cationic fluorocarbon surfactant. } \\
\text { - The particle content in the films depends upon its concentration in the bath. }\end{array}$ & [134] \\
\hline
\end{tabular}


- Studied effect of the PTFE concentration, the current density and the agitation on both the morphology and properties of Ni-PTFE coatings.

- Used a rotating disk electrode to show that well defined hydrodynamic conditions can be taken into Guglielmi model.

- Water repellent coating with maximum $17 \mathrm{wt} \%$. PTFE in the composite.

- Studied the properties of nickel-PTFE composites. useful materials with numerous industrial applications and a promising future, in addition to being materials of great interest to the scientific community. The industrial importance of the refractory carbides is growing rapidly, not only in the traditional and well-established applications based on the strength and refractory nature of these materials such as cutting tools and abrasives but also in new and promising fields such as electronics and opto-electronics. Some typical applications are as follows:

Tungsten-carbide cutting tools, Silicon-carbide fibers and whiskers, Silicon carbide burner tubes for gas furnaces, Silicon carbide high-temperature semiconductor devices, Silicon carbide blue Light-Emitting Diode (LED) and Boron-carbide abrasive blast nozzles.

Interstitial carbides (WC, TiC): The difference in electronegativity between the two elements of the interstitial carbides is large. The carbon atom has a much smaller size than the other atom, allowing it to nest in the interstices of the lattice (hence the name interstitial). The bonding is partly covalent and ionic, but mostly metallic which explains why the interstitial carbides closely resemble metals. Like metallic alloys, their composition is often indeterminate and their electrical and thermal conductivities are high. In addition, they have high melting points, high hardness and are chemically inert.

$\mathrm{Ni}-\mathrm{TiC}$, finds their main use as cutting tools and in wear resistant applications because of their superior hardness and reasonable fracture toughness. TiC reinforced $\mathrm{Cu}$ and Fe based composites [139] have been extensively used in electrical contacts, resistance welding electrodes and electrode for automatic welding. An exhaustive survey of literature reveals that though Ni-TiC metal matrix composites has been investigated by several investigators but very little work has been done particularly on the electrodeposition of $\mathrm{Ni}-\mathrm{TiC}$ composite and most of the reports are patented and operating details are not available. Mostly effects of particle concentration in the bath, current density, $\mathrm{pH}$ and temperature on volume percentage incorporation of TiC particles in the composite electrodeposition of Ni-TiC coating have been investigated and the findings are presented in table 3 .

WC is one of the hard metals widely used in tribological applications and attempts have been made to codeposit WC with Ni metal under different condition. In table 3, informations related to $\mathrm{Ni}-\mathrm{WC}$ composites are given.

Covalent carbides (SiC, $\left.\mathbf{B}_{4} \mathbf{C}\right)$ : The difference in electro negativity between the two elements of the covalent carbides is small. The carbon atom is only slightly smaller than the other atom. The bonding is essentially covalent. Only two covalent carbides, silicon carbide and boron carbide, fully meet the refractory criteria. Other carbides such as beryllium carbide, $\mathrm{Be}_{2} \mathrm{C}$ are only partially covalent and, while they have a high melting point, are generally not chemically stable.

$\mathrm{Ni}$-SiC composite coatings are widely used for protection of friction parts due to their high wear resistance and low cost of ceramic powder. The influence of deposition and bath variables on the structure and properties of few electrodeposited Ni-SiC composites are briefly summarized in Table 3.

Boron carbide is an important non-metallic material with outstanding hardness, excellent mechanical, thermal and electrical properties. Its low density, high chemical inertness and neutron capture cross section make boron carbide an attractive material for micro-electronic, nuclear, military, space and medical applications. This is known to be the third hardest material in terms of its super-abrasiveness and super-hardness [164]. Owing to its open structure and light atoms, $\mathrm{B}_{4} \mathrm{C}$ has a low density $\left(2.52 \mathrm{~g} / \mathrm{cm}^{3}\right)$ and also high melting point $\left(2427^{\circ} \mathrm{C}\right)$. One of the major industrial uses of $\mathrm{B}_{4} \mathrm{C}$ is as an abrasive grit or powder. Particles with diameters in the range from 1 to $10 \mu \mathrm{m}$ are used as polishing, lapping and grinding media for hard materials. For these applications, boron carbide is far less expensive than diamond. Components made of boron carbide are also very often used in wear resistant applications, (e. g., as blast nozzles, wheel dressing tools, and light weight armour plates). $\mathrm{Ni}-\mathrm{B}_{4} \mathrm{C}$ composite coatings find their main uses as hard facing for anti-wear and anti- abrasive surfaces. Literature survey shows substantial research related to nickel as matrix with different ceramic particles as reinforce to produce metal matrix nanocomposite while relatively scanty information is available with the $\mathrm{B}_{4} \mathrm{C}$ (Table 3).

Intermediate carbides: Some transition metals of Groups VII and VIII such as manganese, iron, cobalt, and nickel, as well as chromium of Group VI also form carbides but, their atomic radii are too small to accommodate the carbon atom in interstitial positions without severe distortion of the lattice. The carbon atoms are close enough for carbon-carbon bonds and carbon chains to form. These carbides are not generally chemically stable. They are hydrolyzed by water or by dilute acids to produce hydrocarbons and hydrogen. An exception is chromium carbide, $\mathrm{Cr}_{2} \mathrm{C}_{3}$, which is a refractory border-line case.

Salt-like carbides $\left(\mathrm{Al}_{4} \mathrm{C}_{3}\right)$ : The salt-like (or salinic) carbides are formed with carbon and the most electropositive elements, found in Groups I, II and III to the left of the Periodic Table. These elements have an electronegativity difference of about two or 
Table 3:

\begin{tabular}{|c|c|c|c|}
\hline Matrix & Reinforcement & Remarks & References \\
\hline \multirow{3}{*}{$\mathrm{Ni}$} & \multirow{3}{*}{$\mathrm{TiC}$} & $\begin{array}{l}\text { - Effects of particle concentration in the bath, current density, } \mathrm{pH} \text { and temperature on volume percentage } \\
\text { incorporation of TiC particles in the composite. } \\
\text { - Wear resistant coatings on aluminum motor engines }\end{array}$ & {$[140-142]$} \\
\hline & & $\begin{array}{l}\text { - Watts's bath } \\
\text { - Effect of particle size of carbide powder on TiC incorporation. } \\
\text { Magnetic stirring produces more uniform distribution in the suspension and the amount of embedded } \\
\text { TiC and thus hardness of composite powder increases with decrease in particle size of titanium carbide in } \\
\text { the bath. }\end{array}$ & {$[143]$} \\
\hline & & $\begin{array}{l}\text { - Uses an organic free Watts' nickel electrolyte. } \\
\text { - Optimization of electro-co-deposition conditions. } \\
\text { - Composite coating with matrix crystalline size less than } 40 \mathrm{~nm} \text {. }\end{array}$ & [142] \\
\hline \multirow{6}{*}{$\mathrm{Ni}$} & \multirow{6}{*}{ WC } & $\begin{array}{l}\text { - Composites produced contain } 37-59 \mathrm{vol} \% \mathrm{WC} \text { and in this range microhardness increases linearly ( } 270 \text { to } \\
560 \mathrm{VHN} \text { ) whereas tensile strength decreases ( } 568.8 \text { to } 191.2 \mathrm{MPa} \text { ) with the content of WC. } \\
\text { - Annealing takes place at around } 250^{\circ} \mathrm{C} \text { and the recrystallisation appears to be inhibited due to the } \\
\text { presence of WC particles }\end{array}$ & [144] \\
\hline & & $\begin{array}{l}\text { - Improved microhardness due to dispersion strengthening effect and WC reinforcement in nickel } \\
\text { composite coatings significantly affects the stability of passive film and causes a positive shift in } \\
\text { passivation potential, reduction in passive range and higher passive current densities compared to pure } \\
\text { nickel coatings. }\end{array}$ & [145] \\
\hline & & $\begin{array}{l}\text { - Uses Watts's bath and rotating disc electrode. } \\
\text { - Studied the effect of type of current and hydrodynamic conditions of the plating bath, crystallographic } \\
\text { orientation, the distribution and the percentage of the embedded particles. } \\
\text { - Highly porous deposits under DC condition at low rotation rate while applying PC conditions and high } \\
\text { rotation velocities, compact deposits with high concentration of embedded WC particles, proposed } \\
\text { mechanism of nickel electrocrystallization in the presence of WC particles. }\end{array}$ & [146] \\
\hline & & $\begin{array}{l}\text { - WC embedded in the coating could vary from a few percent to over } 80 \% \text {, under the same conditions } \\
\text { of electrodeposition; higher amounts of embedded WC particles could be obtained from solutions } \\
\text { containing smaller particles. } \\
\text { - Reported that the concentration of insoluble WC particles in the Watts bath has no significant influence } \\
\text { on the amount of WC embedded in the coating. }\end{array}$ & [147] \\
\hline & & $\begin{array}{l}\text { - Studied tensile strength and microhardness and concluded that the improvement in the mechanical } \\
\text { properties is due to the reduction in crystalline size. }\end{array}$ & [148] \\
\hline & & $\begin{array}{l}\text { - Studied the effect of particle size on its incorporation and found that the amount of embedded WC and } \\
\text { thus hardness of composite increases with decrease in particle size }(16-20 \mathrm{~nm}) \text {. }\end{array}$ & [149] \\
\hline \multirow{9}{*}{$\mathrm{Ni}$} & \multirow{9}{*}{$\mathrm{SiC}$} & $\begin{array}{l}\text { - Pulse electrodeposition } \\
\text { - Coatings exhibited four times hardness than annealed nickel and two time hardness than regular grain } \\
\text { size nickel matrix }\end{array}$ & {$[150]$} \\
\hline & & - Evaluated wear and corrosion resistance & [151] \\
\hline & & $\begin{array}{l}\text { - } 20 \mathrm{~nm} \mathrm{SiC} \mathrm{influence} \mathrm{the} \mathrm{competitive} \mathrm{formation} \mathrm{of} \mathrm{nuclei} \mathrm{and} \mathrm{crystal} \mathrm{growth} \mathrm{and} \mathrm{the} \mathrm{presence} \mathrm{of} \\
\text { nanoparticles will perturb the crystalline growth of a metal deposit, resulting in an increased number of } \\
\text { defects in the crystal structure, facilitating a nanocrystalline structure. }\end{array}$ & {$[152,153]$} \\
\hline & & $\begin{array}{l}\text { - Studied the influence of current density and the concentration of particles in the bath. } \\
\text { - Found that increased concentration of SiC in the electrolyte corresponds to increased particle content in } \\
\text { the composite. }\end{array}$ & [154] \\
\hline & & $\begin{array}{l}\text { - Microhardness, wear and corrosion resistance of coatings increases with } \mathrm{SiC} \text { content in the plating bath. } \\
\text { - The increase in microhardness and wear resistance was mainly due to incorporated } \mathrm{SiC} \text { particles which } \\
\text { restrain grain growth as well as plastic deformation and promote the grain refining and dispersive } \\
\text { strengthening. }\end{array}$ & [155] \\
\hline & & $\begin{array}{l}\text { - Reported almost no influence of presence of SiC in nickel matrix on micro hardness of composite. } \\
\text { - Reinforced SiC particles act as a physical barrier to initiation and development of defect corrosion } \\
\text { resulting in improvement in corrosion resistance }\end{array}$ & [156] \\
\hline & & - Exhibited maximum hardness and wear resistance compared to pure nickel. & [157] \\
\hline & & $\begin{array}{l}\text { - Reported significant improvement in mechanical properties including hardness, yield, and tensile stress. } \\
\text { - Improvement in hardness of composites was mainly based on dispersion strengthening mechanism } \\
\text { which is based on dislocation particle interaction. }\end{array}$ & [150] \\
\hline & & $\begin{array}{l}\text { Reported that the codeposition of nano } \mathrm{SiC} \text { particles leads to a } 70 \% \text { decrease of the wear coefficient } \\
\text { at room temperature and an } 88 \% \text { decrease of the wear coefficient at } 300{ }^{\circ} \mathrm{C} \text { in comparison to the pure } \\
\text { nickel deposits. }\end{array}$ & [158] \\
\hline
\end{tabular}




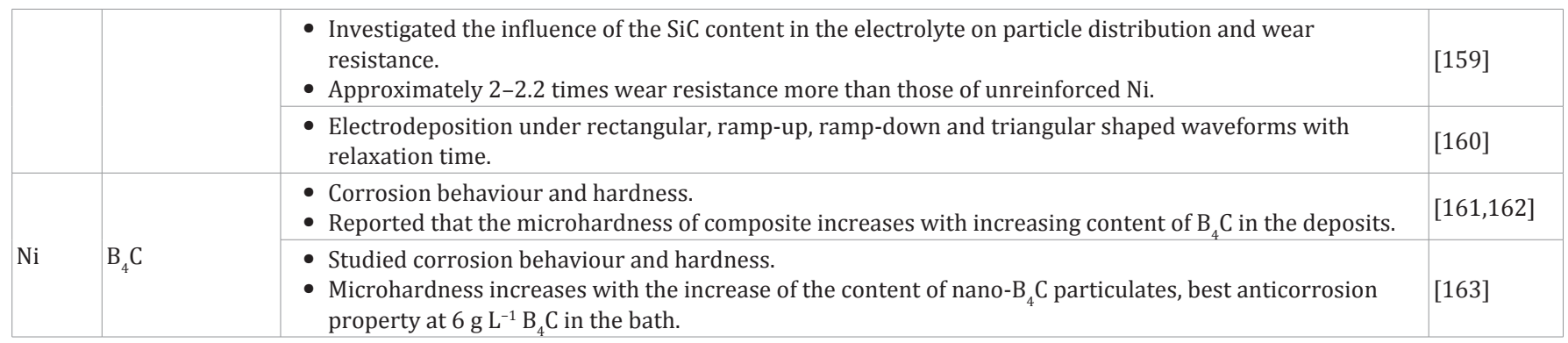

more which corresponds to an atomic bond that is at least $50 \%$ ionic. These compounds have the characteristics of a salt, that is, they have a fixed composition; their physical properties are unlike those of their constituent elements; they are generally transparent to optical radiation and are good electrical insulators. They form transparent and colorless crystals. Some contain $\mathrm{C}^{4-}$ ions such as aluminum carbide $\left(\mathrm{Al}_{4} \mathrm{C}_{3}\right)$ and beryllium carbide $\left(\mathrm{Be}_{2} \mathrm{C}\right)$. They evolve methane when hydrolyzed and for that reason are usually known as methanides. Others contain $\mathrm{C}^{2-}$ ions such as calcium carbide $\left(\mathrm{CaC}_{2}\right)$; they yield acetylene when hydrolyzed and are known as acetylides. Although some of these salt-like carbides have high melting point (for instance beryllium carbide sublimes above $2100^{\circ} \mathrm{C}$ ), they are decomposed readily by water and/or dilute acids at ordinary temperatures and thus do not meet the refractory criteria. However, this does not necessarily detract from their usefulness. Aluminum and beryllium carbides are important industrial materials in several areas such as atomic energy and others.

An exhaustive survey of literature points that hardly any investigation on the electrodeposition of $\mathrm{Ni}-\mathrm{Al}_{4} \mathrm{C}_{3}$ composite has been taken up hitherto.

\section{Characterization of Nanocomposite Coatings}

Several techniques are used to study the morphological, electrochemical, physical and mechanical properties of the coating including SEM-EDS, X-ray Diffraction (XRD), Transmission Electron Microscopy (TEM), X-ray Photoelectron Spectroscopy (XPS), Atomic Force Microscopy (AFM), wear resistance, Microhardness measurement, Electrochemical Impedance Spectroscopy (EIS) and Electrochemical Polarization etc. In order to determine the amount of codeposited particles into the composite coating, the density of the composite can be determined using helium pycnometry due to significant difference in density between pure $\mathrm{Ni}$ and $\mathrm{Ni}$-ceramic nanocomposite. This technique has advantages over other gravimetric methods in that it is non-destructive method and does not need special sample geometry. The volume fraction $\Phi$ of particles in the composite can be evaluated according to the following equation:

$$
\phi=\frac{\rho_{S}-\rho_{\text {matrix }}}{\rho_{\text {particle }}-\rho_{\text {matrix }}}
$$

Where $\rho_{\mathrm{s}}$ is the measured density of the specimen and $\rho_{\text {matrix }}$ and $\rho_{\text {particle }}$ are the standard values of densities of the Ni matrix and dispersed particles, respectively. The weight percent of incorporated particles into the metal matrix can also be determined using EDS analysis. This analysis can be performed both on the surface and in the cross section but this method is not so accurate so its application is limited to semi-quantitative analysis. The weight percent of incorporated particles into the metal matrix can be also estimated by determining the weight of the coating before and after the electrocodeposition process. The coating is then peeled off, dissolved and analyzed using atomicabsorption spectrometry or ICP technique. Frade et al. [77] uses ICP to determine the composition of $\mathrm{Zn}-\mathrm{TiO}_{2}$ nanocomposite. Another technique nowadays used for depth profile analysis of metal matrix nanocomposites is Glow Discharge (GD). In fact, GDs are implemented as routine technique for quality control in many industries (steel, aluminium, car-manufacturing, etc) and as a valuable tool in materials science. This is being used to reveal processes at the surface (e.g. passivation on highly corrosion-resistant stainless steel), as well as to understand the behavior (tribological properties, corrosion, diffusion processes, etc) of surface treatments such as physical or chemical vapour deposition or ion implantation. The emerging impact of GDs either coupled to Optical Emission Spectrometer (OES) or mass spectrometry (MS) for practical surface and thin film analysis is based mainly on many proved remarkable features, including high depth resolution, multielement capability, low detection limits, minimal matrix effects, accurate quantification comparatively low price, easiness of use and high sample throughput. The analytical potential of GD devices for ultra-thin film analysis (less than $10 \mathrm{~nm}$ thick) has emerged during the last few years. Glow discharge coupled with optical emission spectroscopy has been used for qualitative depth profile for two $\mathrm{Zn}-\mathrm{TiO}_{2}$ nanocomposite [165] films prepared under different conditions. They show that a small amount of $\mathrm{TiO}_{2}$ particles is present only near the surface of the film, whereas Ti is distributed throughout the film. GD sources can be employed for the characterization of different types of nanocomposite films like Ni-SiC nanocomposite [12] giving GD-OES information about the metallic matrix thickness and the amount and distribution of the particles through the film. Additionally, a GDs source has been employed as a complementary technique to Scanning Electron Microscopy (SEM) for the characterization and optimization of synthesis procedures of $\mathrm{Ni}-\mathrm{Zn}-\mathrm{TiO}_{2}$ nanocomposites. XRD is a single, essential and most powerful technique in the characterization of the composites which can be used to determine the crystallite size and lattice strain, texture and phases etc. The crystallite size can be obtained using the Voigt function [166] for the analysis of the integral breadths of broadened X-ray diffraction line. In this 
case, the constituent Cauchy and Gaussian components can be obtained from the ratio of full width at half maximum intensity $(2 \omega)$ and integral breadth $(\beta)$. In a single line analysis, the apparent crystallite size ' $D$ ' and strain ' $e$ ' can be related to Cauchy $\left(\beta_{c}\right)$ and Gaussian $\left(\beta_{G}\right)$ widths of the diffraction peak at the Bragg angle $\theta$

$$
\begin{aligned}
& D=\frac{\lambda}{\beta c \cos \theta} \\
& e=\frac{\beta_{G}}{4 \tan \theta}
\end{aligned}
$$

The constituent Cauchy and Gaussian components can be given as

$$
\begin{aligned}
& \beta_{c}=\left(a_{0}+a_{1} \psi+a_{2} \psi^{2}\right) \beta \\
& \beta_{G}=\left(\mathrm{b}_{0}+\mathrm{b}_{1 / 2} \psi+\mathrm{b} l \psi+b_{2} \psi^{2}\right) \beta
\end{aligned}
$$

where $\mathrm{a}_{0}, \mathrm{a}_{1} \& \mathrm{a}_{2}$ are Cauchy constants.

$$
\mathrm{b}_{0}, \mathrm{~b}_{1 / 2}, \mathrm{~b}_{1} \& \mathrm{~b}_{2} \text { are Gaussian constants. }
$$

and $\psi=2 / \beta$ where is the integral breadth obtained from XRD peak

$$
\begin{array}{lll}
\mathrm{a}_{0}=2.0207, & \mathrm{a}_{1}=-0.4803, & \mathrm{a}_{2}=-1.7756 \\
\mathrm{~b}_{0}=0.6420, & \mathrm{~b}_{1 / 2}=1.4187, & \mathrm{~b}_{1=}-2.2043,
\end{array}
$$

The values of Cauchy and Gaussian constants can be taken from the table of Langford [167]. From the XRD pattern of $\mathrm{Ni}_{-} \mathrm{ZrO}_{2}$ composite (Figure 3), the crystallite size $D$ and the lattice strain $e$ are calculated and found to be $13 \mathrm{~nm}$ and 0.0013 corresponding to most intense peak. In order to describe the structure and estimate quantitatively the preferred orientation of the nickel deposits, the relative texture coefficient $\left(\mathrm{RTC}_{(\mathrm{hkl})}\right)$ is calculated, which is defined as:

$$
R T C_{(h k l)}=\frac{I_{h k l} / I^{0}{ }_{h k l}}{\sum I_{h k l} / I^{0}{ }_{h k l}} \times 100
$$

Where $I_{h k l}$ are the diffraction intensities of the (hkl) lines measured in the diffractogram of the deposit and $\mathrm{I}^{\mathrm{Q}}{ }_{\mathrm{kl}}$ are the corresponding intensities of a standard $\mathrm{Ni}$ powder sample randomly oriented. A glimpse of literature available on the metal matrix nanocomposites reveals that the inert particulates present in electrolytic bath, always exert strong influence on the texture of the growing metal layer, even if they are not incorporated in the growing metal. Gyftou et al. [58] have reported that the presence of nanoparticles led to the deterioration of the quality of the [100] preferred orientation and at high concentration of embedded particles ( $\mathrm{SiC}$ ), mixed crystal orientation through [100] and [211] axes was resolved. Spanou et al. [168] are of the opinion that the change of preferred orientation along with decreasing crystallite size of metal matrix in the deposits indicates an effective incorporation or embedding of the particles in the composite. Accordingly, the incorporation of nano sized $\mathrm{SiC}$ in nickel matrix resulted in the deposition of composite with

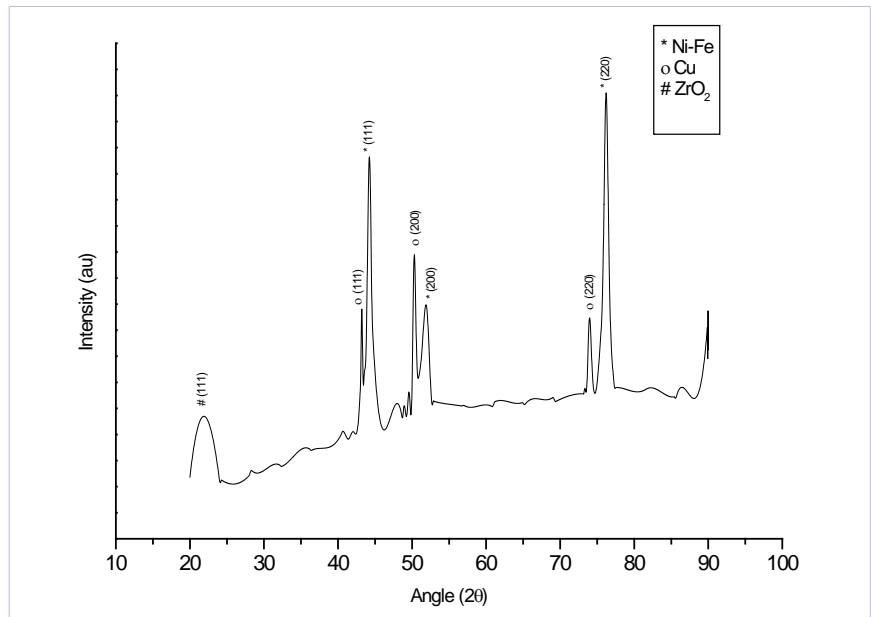

Figure 3: X-ray diffraction pattern of $\mathrm{Ni}-\mathrm{Fe}-\mathrm{ZrO}_{2}$ electro composites deposited at $4 \mathrm{~A} \mathrm{dm}^{-2}$ from bath containing $100 \mathrm{gL}^{-1}$ Nickel sulfamate, $4 \mathrm{gL}^{-1}$ Ferrous sulphate, $5 \mathrm{gL}^{-1} \mathrm{ZrO}_{2}, 30 \mathrm{gL}^{-1}$ Boric acid and $35^{\circ} \mathrm{C}$ and at stirring rate of $500 \mathrm{rpm}$.

smaller crystallite sizes and more structural defects than those of pure Ni deposits [58]. In another work reported by Fustes et al. [76]. XRD was used in qualitative manner to correlate the amount of $\mathrm{TiO}_{2}$ in the $\mathrm{Zn}$ - $\mathrm{TiO}_{2}$ composite coatings with its concentration in the plating bath. For Ni-TiC nanocomposite deposited from $\mathrm{N}$-methylformamide bath a lattice constant $3.452 \AA$ has been reported [87] which is lower than the standard value of the pure metal. This change in the lattice constant of the metal matrix may likely be due to grain refinement [169] caused by incorporation of TiC particles in the growing metal which hinders/alters the grain growth resulting into nanocrystallites of nickel. Goldstein et al. [170] and Gao [171] have reported that nanomaterials may have an appreciably reduced lattice constant than the bulk materials due to a huge fraction of surface atoms in the total amount of atoms.

Scanning Electron Microscope (SEM) equipped with energy dispersive X-ray analyser (EDS) is used to study the surface morphology and elemental composition of the deposits and cross-over sections of the composites. The SEM images of the coatings reveal the characteristic of surface morphology and also confirm particle incorporation and estimate their distribution in the deposited layer [172]. In general, surface of composites is rougher than that of pure metal deposited from particle free bath due to the entrapment of particles [118]. Figure 4 shows the SEM image of Ni-WC nanocomposite electrodeposited from an organic bath in author's laboratory. A cross sectional SEM images of $\mathrm{Ni}-\mathrm{Al}_{2} \mathrm{O}_{3}$ composite coatings were illustrated [94] in order to clarify the composition and qualitative particle distribution induced by modifications of pulse plating parameters. They concluded that the amount of particles could increase due to the variation of these parameters without any modification in the other electrodeposition conditions. Erler et al. [173] also used the cross-section technique to gain information of the particles distribution in the $\mathrm{Ni}^{-\mathrm{TiO}_{2}}$ composite coating. They showed that the particles are not uniformly distributed, in view of the fact that there is an "initial layer with no or very few particles", whatever 


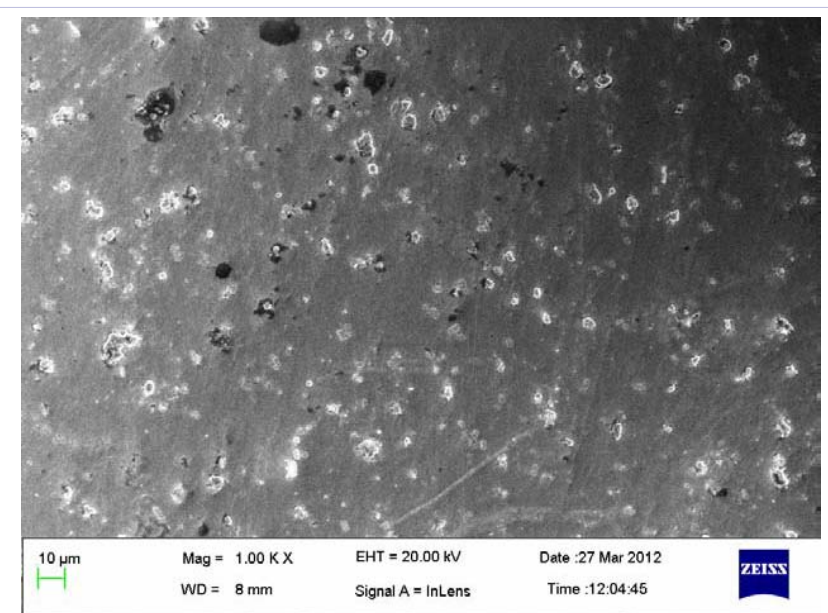

Figure 4: SEM micrograph of Ni-WC composite obtained from a $30 \mathrm{~g} / \mathrm{L}$ particle loading at different current density $2 \mathrm{Adm}-2$ at $55^{\circ} \mathrm{C}$ and at stirring rate of $400 \mathrm{rpm}$.

the particle type is. At the initial stage, super-saturation of nickel atoms adsorption and three-dimensional nucleation can occur only on the substrate particle-free areas. Therefore, a particle free metallic layer has to be deposited by the growth of the initial crystals. Next the particles can stick to the "rough" nickel surface and will be overgrown. The proportion of incorporated particles increases and reaches a stationary value. In general, gradient deposits are obtained from bath containing a gradual increasing or decreasing concentration of particles in the electrolytic bath. However, Low et al. [96] suggested a provision to obtain gradient deposits from a single bath simply by altering the deposition current density or potential and/or by altering the suspension hydrodynamics and bath load.

In addition to the SEM, AFM analysis also provides the surface morphology at the nanometric scale and due to its high resolution imaging; surface roughness values can be estimated [174,175].

Transmission Electron Microscopy (TEM) is the single available tool in materials research which characterises the detail microstructure of composite. Along with the crystallite size and the presence of reinforcement in the deposits, TEM is used to investigate crystallographic defects, dislocation and twining in the composite. TEM images and diffraction pattern of $\mathrm{Ni}$ $\mathrm{Al}_{2} \mathrm{O}_{3}$ electrodeposited composite on the rotating disk electrode, without current modulation were examined [50]. Particles of various diameters ranging from tens to hundreds of nanometers are incorporated into the deposit from the electrolyte containing a distribution of $\gamma-\mathrm{Al}_{2} \mathrm{O}_{3}$ particle sizes. Wang and Wei [176] have observed the clusters of $\mathrm{Al}_{2} \mathrm{O}_{3}$ particles embedded in Ni matrix in the cross-sectional TEM micrograph of the $\mathrm{Al}_{2} \mathrm{O}_{3}$-Ni composite. The diffraction pattern showed a ring pattern, which indicated that the Ni grains are polycrystalline and very small. A similar microstructure was also found for $\mathrm{ZrO}_{2}-\mathrm{Ni}$ and $\mathrm{SiC}-\mathrm{Ni}$ composites, $\mathrm{ZrO}_{2}$ agglomeration containing particles smaller than $20 \mathrm{~nm}$ was observed in the Ni matrix, and there were some pores entrapped in the agglomerate.

X-ray Photoelectron Spectroscopy (XPS) is also used as a characterization tool for metal matrix nanocomposites. XPS provides the information regarding interaction between the metal matrix and the reinforcing particles. The nature of the interactions between $\mathrm{Al}_{2} \mathrm{O}_{3}$ or $\mathrm{SiO}_{2}$ nanoparticles and a nickel metal matrix has been reported by Tu et al. [177] who came at conclusion that there is not only a mechanical connection, but there exists also a chemical combination too between the $\mathrm{Al}_{2} \mathrm{O}_{3}$ or $\mathrm{SiO}_{2}$ nanoparticles and the nickel matrix at the interface in the composite coating.

\section{Properties}

\section{Microhardness}

The hardness test is most valuable and most widely used mechanical test for evaluating the strength of composite materials. The hardness of composite material usually is considered resistance to permanent indentation. Electrochemically deposited composites containing particles of refractory compounds, like oxides, carbides or borides are dispersion hardened compared to the plain metal as evidenced by improved micro hardness. Researchers started to concentrate on the codeposition of smaller particles with metals that could enhance the mechanical properties without penalizing the corrosion resistance of the coating. Moreover the presence of a smaller hard phase could avoid the formation of an abrasive third body during the wear process. Ding et al. [178] used submicron particle sizes of alpha-alumina $(0.11$ micron and 0.4 micron) and observed a linear increase in microhardness in both $\mathrm{Ni}$ and $\mathrm{Cu}$ with particle volume fraction in the deposit. The smaller particles produced a larger hardening effect and the strengthening mechanism was explained by a combination of the Orowan-type strengthening and Hall-Petch effects. Generally the volume fraction of codeposited particles is limited for nanoparticles and usually it is inversely proportional to their size [179]. Shao et al. [180] studied the rate of incorporation of two different sizes of $\mathrm{Al}_{2} \mathrm{O}_{3}$ nanoparticles $(50 \mathrm{~nm}$ and $300 \mathrm{~nm})$ into a nickel deposit. Using similar operating parameters, it was found that the percentage volume fraction of the $300 \mathrm{~nm} \mathrm{Al}_{2} \mathrm{O}_{3}$ in the nickel deposit was much higher compared to the $50 \mathrm{~nm} \mathrm{Al}_{2} \mathrm{O}_{3}$. The hardening effect is therefore related not only to the presence of the second hard phase but also to the changes induced in the metal. The amount of embedded nanoparticles depends on the operational parameters such as current density, $\mathrm{pH}$, bath temperature, additives type and concentration, stirring; but the relationship between operating parameters and codeposition amount is not clear and often the results are inconsistent. Erler et al. [173] demonstrated that alumina nanoparticles content in the deposit increases on decreasing the deposition current. On the contrary Bund et al. [181] show that the embedded fraction of nano alumina is not affected by the current density in acidic nickel deposition bath, while it increases by increasing the current in alkaline deposition bath. The results regarding the effect of particles incorporation on the final properties is often contradictory because it depends on a lot of parameters and on both the embedded amount and the dispersion of the particles. The hardening effect caused by the codeposition of nanoparticles has been reported by many authors $[27,182,183]$. An increase 
in the hardness of nickel nanocomposite film is associated with the presence of the intrinsic hardness of the codeposited ceramic phase, to a dispersion hardening and to the refinement of the microstructure. Lekka et al. [161] prepared and characterized Ni matrix micro- and nano-SiC composite electrodeposits under DC conditions using a nickel sulfammate bath and studied the microstructure, microhardness and wear resistance under high load at both room temperature and $300^{\circ} \mathrm{C}$. They found that the codeposition of the $\mathrm{SiC}$ particles changed the microstructure of the nickel matrix and the preferential orientation of the Ni grains from [100] to [110] leading to a noticeable improvement on both microhardness and wear resistance. The microstructural modifications and the presence of the $\mathrm{SiC}$ particles in the metal matrix led to $51 \%$ increase of the microhardness and a $63 \%$ decrease of the wear coefficient at $300^{\circ} \mathrm{C}$ while it did not offer any improvement at the wear resistance at room temperature. Gulb et al. [159] investigated the influence of the SiC content in the electrolyte on particle distribution, microhardness and wear resistance of nano-composite coatings. The hardness of the coatings was measured to be $280-571 \mathrm{HV}$ depending on the particle volume in the Ni matrix.

\section{Electrical conductivity of metal matrix nanocomposite}

The electrical resistivity of the metal though high enough shows significant changes once any other constituent is mixed in it. The large volume fraction of grain boundaries in nanocrystalline metals typically gives rise to an increased electrical resistivity, which might be an advantage in soft magnetic materials. The reduction of grain size reduces the electrical conductivity of highly conducting metals e.g. copper. The amount of particulate incorporated in the metal matrix of the composites may show interesting results. In view of this the measurement was carried out for the different deposited composites in the present investigation. The results obtained are discussed in the following text.

Figures 5a \& 5b represent the apparent electrical resistivity of nickel matrix reinforced with $\mathrm{TiC}$ and $\mathrm{SiC}$ nanoparticulates coatings obtained in our laboratory from a non-aqueous bath. Electrical resistivity of as deposited nickel film was found to be $0.045 \mathrm{n}^{\prime} \Omega-\mathrm{m}$ and this value is $10^{3}$ fold lower than that of reported [184] for the thin film of nickel obtained by thermal evaporation. Variation in electrical resistivity of Au-ZnO nanocomposite films prepared by electron beam codeposition techniques was investigated [185] and it has been found that the electrical resistivity increases monotonically with increasing $\mathrm{ZnO}$ content however it represents three marked characteristic regimes of behavior associated primarily with (1) grain boundary electron scattering due to grain refinement at $\mathrm{ZnO}$ volume fractions below 0.3 ,

(2) percolation theory for $\mathrm{ZnO}$ volume fractions at and above the percolation threshold $\left(f_{c}=0.85\right)$ and

(3) a transition region between these where it was proposed that resistivity was influenced by the formation of $\mathrm{Au}-\mathrm{Zn}$ complexes due to an oxygen deficiency in the deposited $\mathrm{ZnO}$.

Chang et al. [186] has also reported that the resistivity of the

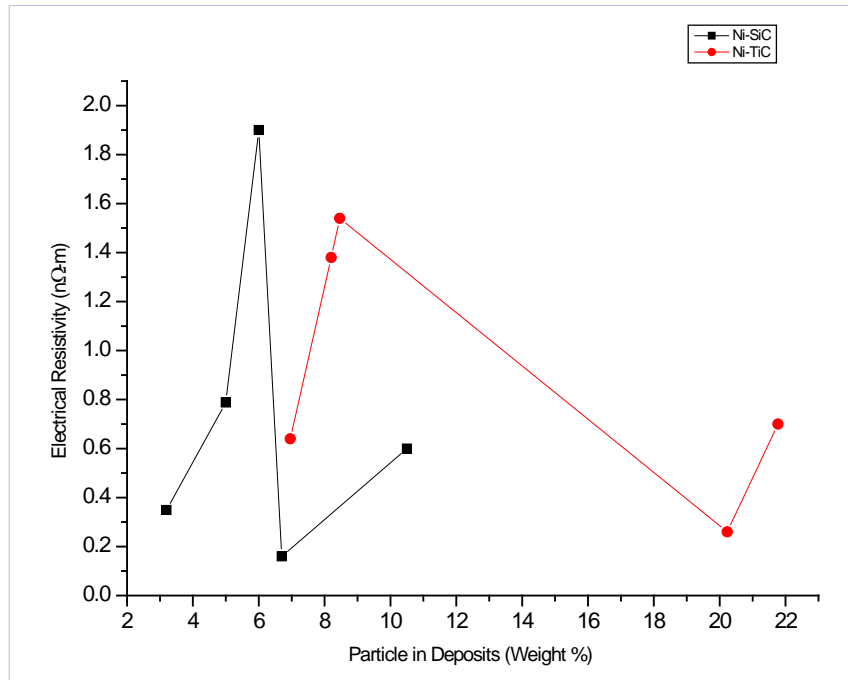

Figure 5a: Electrical resistivity of $\mathrm{Ni}-\mathrm{TiC}$ and $\mathrm{Ni}-\mathrm{SiC}$ composites vs. weight \% incorporation of reinforcement in deposits. [TiC $(<200 \mathrm{~nm})$, $\operatorname{SiC}(<100 \mathrm{~nm})]$

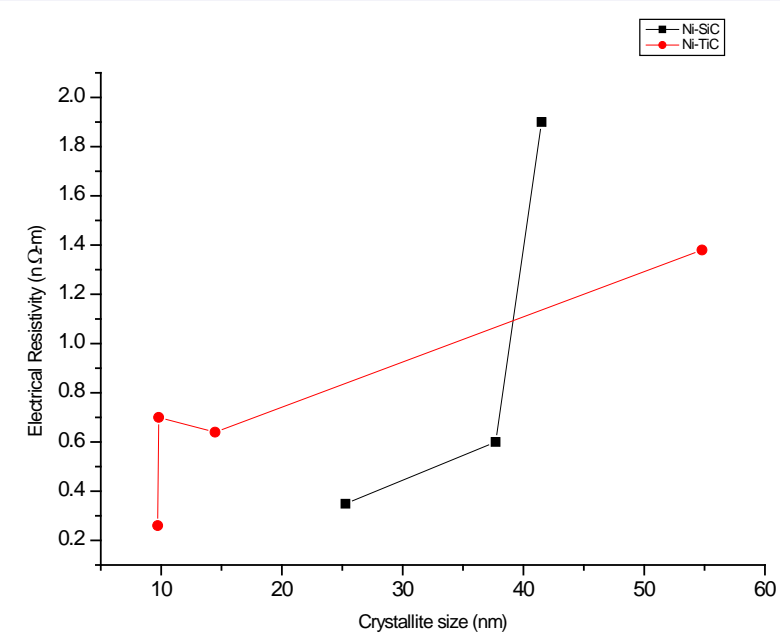

Figure 5b: Electrical resistivity of $\mathrm{Ni}-\mathrm{TiC}$ and $\mathrm{Ni}-\mathrm{SiC}$ composites vs. crystallite size. [TiC $(\sim 8.2-21.77 \mathrm{Wt}$. \%) and $\operatorname{SiC}(\sim 3.2-10.2 \mathrm{Wt}$. \%)].

composites increases with increasing fraction of reinforcement in the deposit. The variation in the value of experimental electrical resistivity of the composite with respect to wt \% of ceramic particulate in the composite and with respect to crystallite size as shown in Figures $5 \mathrm{a} \& 5 \mathrm{~b}$ has been analyzed in light of scattering, size domain, and film thickness, size of reinforcement, residual stress and dislocation density [187]. Since resistivity has been measured at room temperature, therefore the surface scattering may be omitted which is a temperature dependent phenomenon. Electrical resistivity of film has an inverse relation with thickness of the film. For a reinforcement size below $10 \mu \mathrm{m}$, the dislocation density has been reported to increase drastically [188]. With decreasing reinforcement size, the total stress and dislocation formed around the reinforcement enhanced the resistivity of the composites. In the present investigation the coatings were prepared under such conditions that the presence of residual 
stress and dislocation is expected to be greatly reduced. Also a fairly stable bath and inert particles have been used therefore the formation and incorporation of any decomposition product in the composite or at the interfaces can be ignored and thus could be considered as almost cleaned interfaces without any reaction product and dissolved particles, Such interface are known to decrease electrical resistivity [189].

\section{Conclusion}

There seems to be much scope for investigation in metal matrix nanocomposites involving variety of metals and particulate materials. This can open many frontiers in development of new exotic composite materials and newer technological industrial/ engineering applications. Since the size of particulate material and matrix as well are in nano range which would provide peculiar properties depending on their size, distribution, content in the composite materials. To further improve the stability of their outstanding functional properties in more well defined, accurate and predictive manner, the understanding of correlations among processing conditions and structural features is needed. For the purpose of characterization of metal matrix nanocomposites for their respective surface morphology, microstructure, phase composition, crystallography and composition a variety of complementary analytical tools such as SEM, TEM, XRD, EDS, GD and AAS are available which can contribute more to clearer understanding. In particular, the minimal matrix effects typical of GD based techniques allow reliable quantitative depth information with good detection limits and fast analysis times. Also electrolytic method being comparatively a greener route of preparation, much more can be thought of deeply in the direction to improving the technique, change in the composition of the electrolytic bath, operating conditions etc to bring it at a larger scale and to keep under more rigorously controlled conditions . Electro crystallization process can also be tuned by governance of plating parameters to achieve desired structure/shape/ properties of the nanocomposites.

\section{Acknowledgement}

Financial assistance provided by the Council of Scientific and Industrial Research (CSIR), and UGC New Delhi, India for providing RFSMS fellowship to one of the author 'DKS', is gratefully acknowledged.

\section{References}

1. Gierlotka D, Rowinski E, Budniok A, Lagiewka E. Production and properties of electrolytic $\mathrm{Ni}-\mathrm{P}-\mathrm{TiO}_{2}$ composite layers. J Appl Electrochem. 1997 ; (27): 1349-1354. doi: 0021-891X.

2. Jepsen DW, Marcus M. Phys Rev Lett. 1998; (13): 11.

3. Sekino T, Nakajima T, Niihara K. Mechanical and Magnetic Properties of Nickel Dispersed Alumina-Based Nanocomposite. Mat Lett. 1996; 29(1-3): 165-169. doi: 10.1016/S0167-577X(96)00136-X.

4. Roy R, Roy RA, Roy DM. Alternative perspectives on "quasicrystallinity": Non-uniformity and nanocomposites. Mater Lett. 1986; 4(8-9): 323-328. doi: 10.1016/0167-577X(86)90063-7.

5. Stiernitzke M. Review: structural ceramic nanocomposites. J Eur Cer Soc. 1997; 17(9): 1061-1082. doi: 10.1016/S0955-2219(96)00222-1.
6. Riedel H, Kleebe J, Schonfelder H, Aldinger F. Nature. 1995; (374): 526.

7. Sawaguchi A, Toda K, Niihara K. Mechanical and electrical-properties of al2o3/sic nano-composites. J Ceram Soc Jpn. 1991; 99(6): 523-526.

8. Lambeth DN, Velu EMT, Bellesis GH, Lee LL, Laughlin DE. Media for $10 \mathrm{~Gb} / \mathrm{in}(2)$ hard disk storage: Issues and status. J Appl Phys. 1996; 79(8): 4496-4501. doi:10.1063/1.361876.

9. Ozkar S, Ozin GA, Prokopowicz RA. photooxidation of hexacarbonylmolybdenum $(0)$ in sodium zeolite y to yield redoxinterconvertible molybdenum(v1) oxide and molybdenum(1v) oxide monomers. Chem Mater. 1992; 4(6): 1380-1388. doi: 10.1021/ cm00024a046.

10. Vazquez-Gomez L, Cattarin S, Guerriero P, Musiani M. Preparation and electrochemical characterization of $\mathrm{Ni}+\mathrm{RuO} 2$ composite cathodes of large effective area. Electrochim Acta. 2007; 52(28): 8055-8063. Doi: 10.1016/j.electacta.2007.06.083.

11. Parvin N, Assadifard R, Safarzadeh P, Sheibani S, Marashi P. Preparation and mechanical properties of SiC-reinforced Al6061 composite by mechanical alloying. Mater Sci Eng A. 2008; 492(1-2): 134-140. doi:10.1016/j.msea.2008.05.004.

12. Lekka M, Zanella C, Klorikowska A, Bonora P L. Scalingup of the electrodeposition process of nanocomposite coating for corrosion and wear protection. Electrochim Acta. 2010; 55(27): 7876-7883. doi:10.1016/j.electacta.2010.02.081.

13. Viswanathan V, Laha T, Balani K, Agarwal A, Seal S. Challenges and advances in nanocomposite processing techniques. Mater Sci Eng R. 2006; 54(5-6): 121-285. doi:10.1016/j.mser.2006.11.002.

14. Musiani M. Electrodeposition of composites: an expanding subject in electrochemical materials science. Electrochim Acta. 2000; 45(20): 3397-3402. doi: 10.1016/S0013-4686(00)00438-2.

15.Zhitomirsky I, Gal-or L, Kohn A, Hennicke HW. Electrodeposition of ceramic films from non-aqueous and mixed solutions. J Mater Sci. 1995; 30: 5307-5312.

16. Peulon S, Lincot D. Mechanistic study of cathodic electrodeposition of zinc oxide and zinc hydroxychloride films from oxygenated aqueous zinc chloride solutions. J of Electro Chem. 1998; 145(3): 864-874. doi: $10.1149 / 1.1838359$.

17.Zotti G, Schiavon G, Zecchin S, Casellato U. Electrodeposition of Amorphous $\mathrm{Fe}_{2} \mathrm{O}_{3}$ Films by Reduction of Iron Perchlorate in Acetonitrile. J Electrochem Soc. 1998; (145): 385-389. doi: 10.1149/1.1838273.

18. Abolmali SB, Talbot JB. Synthesis of superconductive thin-films of YBA2CU307-X by a nonaqueous electrodeposition process. J Electrochem Soc. 1999; (140): 443-445.

19.Zhitomirsky I, Gal-Or L, (1999), Intermetallic and Ceramic Coatings, ed. Narenda B Dahotre and TS Sudarshan (New York: Marcel Dekker) pp. 83-145.

20. Ban S, Maruno S, (1993). Deposition of calcium-phosphate on titanium by electrochemical process in simulated body-fluid. Jpn J Appl Phys Part 2-Lett, 32 (10B), L1577-L1580.

21. Konno H, Tokita M, Furusaki A, Furuichi R. Electrochemical Formation Of A-Site Substituted Perovskite Structure $\mathrm{La}_{1-\mathrm{x}} \mathrm{M}_{\mathrm{x}} \mathrm{CrO}_{3}$ Oxide Coatings. Electrochim Acta. 1992; 37(13): 2411-2416. doi: 10.1016/00134686(92)87077-D.

22. Yoshino T, Baba N. Characterization and properties of electrochromic cobalt oxide thin film prepared by electrodeposition. Solar Energy Materials and Solar Cells. 1995; 39(2-4): 391-397. doi: 10.1016/0927- 


\section{8(96)80004-3}

23. Zhitomirsky I, Chaim R, Gal-or L, Bestgen H. Electrochemical $\mathrm{Al}_{2} \mathrm{O}_{3}$ $\mathrm{Cr}_{2} \mathrm{O}_{3}$ alloy coatings on non-oxide ceramic substrates. J Mater Sci. 1997; (32): 5205-5213

24. Chandrasekar MS, Pushpavanam M. Pulse and pulse reverse platingConceptual, advantages and applications. Electrochim Acta. 2008; (53): 3313-3322. doi:10.1016/j.electacta.2007.11.054.

25. Jakob C, Erler F, Nutsch R, Steinhauser S, Wielage B, Zschunke A. Proc. 15th InterfinishWorld Congr and Exhibition, Garmisch-Partenkirchen. 2000.

26. Hovestad A, Janssen LJJ. Electrochemical codeposition of inert particles in a metallic matrix. J Appl Electrochem. 1995; 25(6): 519-527.

27. Pavlatou EA, Stroumbouli M, Gyftou P, Spyrellis N. Hardening effect induced by incorporation of $\mathrm{SiC}$ particles in nickel electrodeposits. Appl Electrochem. 2006; 36(4): 385-394. doi: 10.1007/s10800-0059082-y.

28. Vittal R, Gomathi H, Kim KJ. Beneficial role of surfactants in electrochemistry and in the modification of electrodes. Advances in Colloid and Interface Science. 2006; 119(1): 55-68. doi:10.1016/j. cis.2005.09.004.

29. Aslanidis D, Fransaer J, Celis JP. The electrolytic codeposition of silica and titania modified silica with zinc. J Electrochem Soc. 1997; 144 (7): 2352-2357. doi:10.1149/1.1837817.

30. Low CTJ, Wills RGA, Walsh FC. Electrodeposition of composite coatings containing nanoparticles in a metal deposit. Surf Coat Technol. 2006 201(1-2): 371-383. doi:10.1016/j.surfcoat.2005.11.123.

31. Lampke Th, Leopold A, Dietrich D, Alisch G, Wielage B. Correlation between structure and corrosion behaviour of nickel dispersion coatings containing ceramic particles of different sizes. Surf Coat Technol. 2006; 201(6): 3510-3517. doi:10.1016/j. surfcoat.2006.08.073.

32. Stappers L, Fransaer J.Growth of metal around particles during electrodeposition. J Electrochem Soc. 2006; 153(7): C472-C482. doi $10.1149 / 1.2198090$

33. Dedeloudis C, Fransaer J, Celis JP. Surface force measurements at a copper electrode/electrolyte interface. J. Phys. Chem. B. 2000; 104(9): 2060-2066. doi: 10.1021/jp9931814.

34. Vidrich G, Castagnet JF, Ferkel H. Dispersion Behavior of $\mathrm{Al}_{2} \mathrm{O}_{3}$ and $\mathrm{SiO}_{2}$ Nanoparticles in Nickel Sulfamate Plating Baths of Different Compositions. J Electrochem Soc. 2005;152(5): C294-C297. doi: $10.1149 / 1.1885286$

35. Bicelli LP, Bozzini B, Mele C, D’Urzo L. A Review of Nanostructural Aspects of Metal Electrodeposition. Int J Electrochem Sci. 2008; (3): $356-408$.

36. Whithers JC. Prod Fin. 1962; (26): 62.

37. Williams RV, Martin PW. Trans Inst Met Finish. 1964;(42): 182.

38. Brandes EA, Goldthorpe D. Metallurgia. 1967; (76): 195

39. Saifullin RS, Khalilova RG. J Appl Chem USSR. 1970; (43): 1266.

40. Bazard R, Boden PJ. Trans Inst Met Finish. 1972; (50): 63.

41. Guglielmi N. Kinetics of the Deposition of Inert Particles from Electrolytic Baths. J Electrochem Soc. 1972; 119(8): 1009-1012. doi $10.1149 / 1.2404383$

42. Foster J, Kariapper AMJ. Trans Inst Met Finish. 1973; 54: 27.
43. Valdes JL, (1987). Ph.D. thesis, Columbia University, New York

44. Eng Y, (1991). Ph.D. Thesis, Columbia University, New York

45. Celis JP, Roos JR, Buelens C. A mathematical model for the electrolytic codeposition of particles with a metallic matrix. J. Electrochem. Soc. 1987; 134(6): 1402-1408. doi: 10.1149/1.2100680.

46. Fransaer J, Celis JP, Roos JR. Analysis of the Electrolytic Codeposition of Non-Brownian Particles with Metals. J Electrochem Soc. 1992; 139(2): 413-425. doi: 10.1149/1.2069233.

47. Hwang BJ, Hwang CS. Mechanism of Codeposition of Silicon Carbide with Electrolytic Cobalt. J Electrochem Soc. 1993; 140(4): 979-984. doi:10.1149/1.2056239.

48. Vereecken PM, Shao I, Searson PC. Particle codeposition in nanocomposite films. J. Electrochem.Soc. 2000; 147: 2572-2575. doi: $10.1149 / 1.1393570$

49. Lee J, Talbot JB. A model of electrocodeposition on a rotating cylinder electrode. J. Electrochem. Soc. 2007; 154: D70-D77.

50.Vidrine $\mathrm{AB}$, Podlaha EJ. Composite electrodeposition of ultrafine gamma-alumina particles in nickel matrices-Part I: Citrate and chloride electrolytes. J. Appl. Electrochem. 2001; 31: 461-468.

51. Watson SW. Electrochemical study of SiC particle occlusion during nickel electrodeposition. J Electrochem Soc. 1993; 140 (8): 2235-2238. doi: 10.1149/1.2220801.

52. Benea L. Electrodeposition and tribocorrosion behaviour of $\mathrm{ZrO}_{2}-\mathrm{Ni}$ composite coatings. J Appl Electrochem. 2009; 39(10): 1671-1681.

53. Podlaha EJ, Landolt D. J Electrochem Soc. 1997; (144): L200.

54. Webb PR, Robertson NL. J Electrochem Soc. 1994; (141): 669.

55. Stojak JL, Talbot JB. Effect of particles on polarization during electrodeposition using a rotating cylinder electrode. J Appl Electrochem. 2001; 31(5): 559-564.

56. Fink CG, Prince JD. Trans Am Electrochem Soc. 1928; (54): 315.

57.Williams RV. Electroplat Met Finish. 1966; (19): 92.

58. Stroumbouli M, Gyftou P, Pavlatou EA, Spyrellis N. Codeposition of ultrafine WC particles in Ni matrix composite electrocoatings. Surf Coat Technol. 2005; 195: 325. doi: 10.1016/j.surfcoat.2004.06.034.

59. Aal AA, Hassan HB. Electrodeposited nanocomposite coatings for fuel cell application. Journal of Alloys and Compounds. 2009; 477(1-2): 652-656. doi:10.1016/j.jallcom.2008.10.116.

60. Sautter FK. J Electrochem Soc. 1963; (110): 557.

61. Thiemig D, Bund A, Talbot JB. Influence of hydrodynamics and pulse plating parameters on the electrocodeposition of nickel-alumina nanocomposite films. Electrochim Acta. 2009; (54): 2491-2498. doi:10.1016/j.electacta.2008.04.004.

62. Chang YS, Lee JY. Wear resistant nickel composite coating from bright nickel baths with suspended very low concentration alumina. Mater Chem Phys. 1988; 20(4-5): 309 -371. doi: 10.1016/02540584(88)90071-5.

63. Graydon JW, Kirk DW. J Electrochem Soc. 1989; (136): 3545.

64. Bapu GNKR, Yusuf MM. Mat Chem Phys. 1993; (36): 134.

65. Poiana M, Dobromir M, Nica V, Sandu I, Georgescu V. Microstructure, Magnetic and Electronic Transport Properties of $\mathrm{Co}_{-} \mathrm{TiO}_{2}$ Nanocomposite Films in Metal Matrix. J Supercond Nov Magn. 2013; 26(10): 3105-3114. doi: 10.1007/s10948-013-2126-3. 
66. Shahri Z, Allahkaram SR, Zarebidaki A. Electrodeposition and characterization of Co-BN (h) nanocomposite coatings. Appl Surf Sci. 2013; (276): 174-181. doi: 10.1016/j.apsusc.2013.03.062.

67. Li Y, Zhao A, Wang B, Li J, Wu F. Matrix microstructure deteriorations resulting from diamond incorporation in electroplated metaldiamond composites. Surf Coat Technol. 2008; (202): 1357-1363. doi:10.1016/j.surfcoat.2007.06.029.

68. Orkut S, Mustafa E, Bahattin A, Erdal C. Electro-codeposited CrSiC composite coatings: effect of the pulse-current frequency on morphology and hardness. Materiali In Tehnologije. 2013; (47): 601604.

69. Hamid ZA, Ghayad IM, Ibrahim KM. Surf Inter Anal. 2005; 37: 573.

70. Li H, Wan Y, Liang H, Li X, Huang Y, He F. Composite electroplating of $\mathrm{Cu}-\mathrm{SiO}_{2}$ nano particles on carbon fiber reinforced epoxy composites. Appl Surf Sci. 2009; 256(5): 1614-1616. doi:10.1016/j. apsusc.2009.04.148.

71.Zamblau I, Varvara S, Muresan LM. Corrosion behavior of $\mathrm{Cu}-\mathrm{SiO}_{2}$ nanocomposite coatings obtained by electrodeposition in the presence of cetyl trimethyl ammonium bromide. J Mater Sci. 2011; 46(20): 6484-6490. doi: 10.1007/s10853-011-5594-5.

72. Gan Y, Lee D, Chen X, Kysar JW. Structure and properties of electrocodeposited $\mathrm{Cu}-\mathrm{Al}_{2} \mathrm{O}_{3}$ nanocomposite thin films. J Eng Mater Technol. 2005; (127): 451-456. doi: 10.1115/1.1925292.

73. Ger MD. Electrochemical deposition of nickel/SiC composites in the presence of surfactants. Mat Chem Phys. 2004; (87): 67-74. doi: 10.1016/j.matchemphys.2004.04.022.

74. Li J, Xie H, Li Y. Fabrication of gold nanoparticles/polypyrrole composite-modified electrode for sensitive hydroxylamine sensor design. J Solid State Electrochem. 2012; 16(2): 795-802. doi: 10.1007/ s10008-011-1431-7.

75. Frade T, Melo Jorge ME, Gomes A. Annealed $\mathrm{Zn}-\mathrm{TiO}_{2}$ nanocomposites electrodeposited: Effect of the substrate. Surf Coat Technol. 2012; 206(16): 3459-3466. doi: 10.1016/j.surfcoat.2012.02.012.

76. Fustes J, Gomes A, da Silva Pereira MI. Electrodeposition of ZnTiO2 nanocomposite films-effect of bath composition. J Solid State Electrochem. 2008; 12(11): 1435-1443. doi: 10.1007/s10008-0070485-z.

77. Frade T, Bouzon V, Gomes A, da Silva Pereira M I. Pulsed-reverse current electrodeposition of $\mathrm{Zn}$ and $\mathrm{Zn}-\mathrm{TiO}_{2}$ nanocomposite films. Surf Coat Technol. 2010; (204): 3592-3598. doi:10.1016/j. surfcoat.2010.04.030.

78. Tuaweri TJ, Wilcox GD. Behaviour of $\mathrm{Zn}-\mathrm{SiO}_{2}$ electrodeposition in the presence of N, N-dimethyldodecylamine. Surf Coat Technol. 2006; (200): 5921-5930. doi:10.1016/j.surfcoat.2005.09.023.

79. Bindiya S, Basavanna S, Naik YA. Electrodeposition and Corrosion Properties of $\mathrm{Zn}-\mathrm{V}_{2} \mathrm{O}_{5}$ Composite Coatings. JMEPEG. 2012; 21(9): 1879-1884. doi: 10.1007/s11665-011-0099-6.

80. Kanagalasara V, Venkatesha TV. Studies on electrodeposition of Zn$\mathrm{MoS}_{2}$ nanocomposite coatings on mild steel and its properties. J Solid State Electrochem. 2012; 16(3): 993-1001. doi: 10.1007/s10008011-1475-8.

81. Vathsala $\mathrm{K}$, Venkatesha TV. $\mathrm{Zn}-\mathrm{ZrO}_{2}$ nanocomposite coatings: Elecrodeposition and evaluation of corrosion resistance. Appl Surf Sci. 2011; (257): 8929-8936. doi:10.1016/j.apsusc.2011.05.067.

82. Dedeloudis C, Kaisheva MK, Muleshkov N, Muleshkov T, Nowak P, Fransaer J, et al. Plat Surf Finish. 1999; 86: 57.
83. Tripathi MK, Singh DK, Singh VB. Electrodeposition of Ni-Fe/BN Nano-Composite Coatings from a Non-aqueous Bath and Their Characterization. Int J Electrochem Sci. 2013; (8): 3454-3471.

84. Singh VB, Pandey P. Electrodeposition of nickel composites from water-diethanolamine bath. Surf Coat Technol. 2006; (200): 45114514. doi:10.1016/j.surfcoat.2005.03.017.

85. Singh DK, Singh VB. Electrodeposition and characterization of Ni-TiC composite using N-methylformamide bath. Mater Sci Eng A. 2012; (532): 493-499. doi:10.1016/j.msea.2011.10.115.

86. Singh DK, Tripathi MK, Singh VB. Electrocodeposition and characterization of $\mathrm{Ni}-\mathrm{WC}$ composite coating from non-aqueous bath. Int J Mat Sci Appl. 2013; 2(2): 68-73. doi: 10.11648/j. ijmsa.20130202.16.

87. Singh DK, Singh VB. Electrodeposition of Ni-SiC Composite from a Non-Aqueous Bath. J Electrochem Soc. 2011; 158(2): D114-D118 . doi: 10.1149/1.3525594.

88. Singh DK, Tripathi MK, Singh VB. Preparation of Ni-TiC Nanocomposites by Electrolytic Codeposition from a Non Aqueous Bath and Their Characterization. J Electrochem Soc. 2012; 159(8): D469-D472. doi: 10.1149/2.038208jes.

89. Corni I, Chater RJ, Boccaccini AR, Ryan MP. Electro co-deposition of $\mathrm{Ni}-\mathrm{Al}_{2} \mathrm{O}_{3}$ composite coatings. J Mater Sci. 2012; 47(14): 5361-5373.

90. Wang W, Hou FY, Wang H, Guo HT. Fabrication and characterization of $\mathrm{Ni}-\mathrm{ZrO}_{2}$ composite nano-coatings by pulse electrodeposition. Scripta Materialia. 2005; (53): 613-618. doi:10.1016/j. scriptamat.2005.04.002.

91. Aruna ST, Bindu CN, Ezhil Selvi V, William Grips VK, Rajam KS. Synthesis and properties of electrodeposited $\mathrm{Ni} /$ ceria nanocomposite coatings. Surf Coat Technol. 2006; (200): 6871-6880. doi:10.1016/j. surfcoat.2005.10.035.

92. Dong S, Du L, Xu B, Yang H, Wu Y. Preparation, microstructure and tribological properties of nano- $\mathrm{Al}_{2} \mathrm{O}_{3} / \mathrm{Ni}$ brush plated composite coatings. Surf Coat Technol. 2005; (192): 311-316. doi:10.1016/j. surfcoat.2004.06.008.

93. García-Lecina E, García-Urrutia I, Diez JA, Morgiel J, Indyka P. A comparative study of the effect of mechanical and ultrasound agitation on the properties of electrodeposited $\mathrm{Ni} / \mathrm{Al}_{2} \mathrm{O}_{3}$ nanocomposite coatings. Surf Coat Technol. 2012; 206(11-12): 2998-3005. doi:10.1016/j.surfcoat.2011.12.037.

94. Bahrololoom ME, Sani R. The influence of pulse plating parameters on the hardness and wear resistance of nickel-alumina composite coatings. Surf Coat Technol. 2005; 192(2-3): 154-163. doi:10.1016/j. surfcoat.2004.09.023.

95. Benea L, Wenger F, Ponthiaux P, Celis JP. Improved hardness and tribocorrosion properties of nickel coatings by co - depositing $\mathrm{ZrO}_{2}$ micro - sized dispersed phase during electroplating process, The annals of "DUNAREA DE JOS" university of galati Ofascicle ix metallurgy and materials science. 2006.

96. Parida G, Chaira D, Basu A. Ni-ZrO ${ }_{2}$ Composite Coating by Electro-CoDeposition. Trans Indian Inst Met. 2013; 66(1), 5-11.

97. Borkar T, Harimkar SP. Surf Coat Technol. 2011; 205: 4124.

98. Li S, Dai C, Wang D, Hu X. Electroforming of nickel and partially stabilized zirconia (Ni + PSZ) gradient coating. Surf Coat Technol. 1997; 91(1-2): 131-135. PI1 S0257-8972(96)03156-S.

99. Lajevardi SA, Shahrabi T, Hasannaeimi V. Synthesis and mechanical properties of nickel-titania composite coatings. Mater Corros. 2011; 


\section{2(1): 29-34. doi: 10.1002/maco.200905467.}

100. Li Q, Yang X, Zhang L, Wang J, Chen B. Corrosion resistance and mechanical properties of pulse electrodeposited $\mathrm{Ni}-\mathrm{TiO}_{2}$ composite coating for sintered NdFeB magnet. J Alloys Compounds. 2009; (482): 339-344. doi:10.1016/j.jallcom.2009.04.014.

101. Sun XJ, Li JG. Friction and Wear Properties of Electrodeposited Nickel-Titania Nanocomposite Coatings. Tribol Lett. 2007; 28(3): 223-228. doi:10.1007/s11249-007-9254-5.

102. Zhou M, de Tacconi NR, Rajeshwar K. Preparation and characterization of nanocrystalline composite (nanocomposite) films of titanium dioxide and nickel by occlusion electrodeposition. J Electroanal Chem. 1997; 421(1-2): 111-120. doi:10.1016/S00220728(96)04825-5.

103. Hassan SF. Effect of primary processing techniques on the microstructure and mechanical properties of nano- $\mathrm{Y}_{2} \mathrm{O}_{3}$ reinforced magnesium nanocomposites. Mat Sci Eng A. 2011; 528(16-17): 5484-5490. doi:10.1016/j.msea.2011.03.063.

104. Srivastava M, Balaraju JN, Ravishankar B, Rajam KS. Improvement in the properties of nickel by nano- $\mathrm{Cr}_{2} \mathrm{O}_{3}$ incorporation. Surf Coat Technol. 2010; 205(1): 66-75. doi:10.1016/j.surfcoat.2010.06.004.

105. Socha RP, Nowak P, Laajalehto K, Väyrynen J. Particle-electrode surface interaction during nickel electrodeposition from suspensions containing $\mathrm{SiC}$ and $\mathrm{SiO} 2$ particles. Colloids and Surfaces A: Physicochem Eng Aspects. 2004; 235(1-3): 45-55. doi:10.1016/j. colsurfa.2004.01.011

106. Yu SR, Liu Y, Li W, Liu JA, Yuan DS. The running-in tribological behavior of nano- $\mathrm{SiO}_{2} / \mathrm{Ni}$ composite coatings. Composites Part B: Engineering. 2012; 43(3): 1070-1076. doi:10.1016/j. compositesb.2011.08.033.

107. Hasannejad H, Shahrabi T. Jafarian M, Rouhaghdam AS. EIS study of nano crystalline $\mathrm{Ni}$-cerium oxide coating electrodeposition mechanism. J Alloys Compounds. 2011; 509(5): 1924-1930. doi:10.1016/j.jallcom.2010.10.089.

108. Gitanjaly, Singh H, Singh S, Prakash S. Role of CeO2 coating in enhancing high temperature corrosion resistance of $\mathrm{Ni}$-base superalloys as an inhibitor. Materials at High Temperatures. 2010; 27(2): 109-116.

109. Tavares AC, Trasatti $\mathrm{S}$. $\mathrm{Ni}+\mathrm{RuO}_{2}$ co-deposited electrodes for hydrogen evolution. Electrochim Acta. 2000; 45(25-26): 41954202. doi:10.1016/S0013-4686(00)00546-6.

110. Gomez LV, Cattarin S, Guerriero P, Musiani M. Preparation and electrochemical characterization of $\mathrm{Ni}+\mathrm{RuO} 2$ composite cathodes of large effective area. Electrochim Acta. 2007; 52(28): 8055-8063. doi:10.1016/j.electacta.2007.06.083.

111. Gómez LV, Cattarin S, Guerriero P, Musiani M. Influence of deposition current density on the composition and properties of electrodeposited $\mathrm{Ni}+\mathrm{RuO} 2$ and $\mathrm{Ni}+\mathrm{IrO} 2$ composites. J Electroanal Chem. 2009; 634(1): 42-48. doi:10.1016/j.jelechem.2009.07.009.

112. Geng S, Qi S, Zhao Q, Zhu S, Wang F. Electroplated Ni-Fe2O3 composite coating for solid oxide fuel cell interconnect application. International Journal of Hydrogen Energy. 2012; 37(14), 10850 10856. doi:10.1016/j.ijhydene.2012.04.043.

113. Jovic VD, Lacnjevac UC, Jovic BM, Gajić-Krstajić LM, Krstajic NV. $\mathrm{Ni}-\mathrm{MoO} 2$ composite cathodes for hydrogen evolution in alkaline solution: Effect of aging of the electrolyte for their electrodeposition. Journal of the Serbian Chemical Society. 2013; 78(5): 689-700. doi: 10.2298/JSC120831112J.
114. Kumar CP, Venkatesha TV. Electrodeposition, characterization and corrosion behavior of Ni-Si3N4 composites. Phys Scr. 2012; 86(1): 1-8. doi:10.1088/0031-8949/86/01/015804.

115. Chan KC, Wang GF, Wang CL, Zhang KF. Low temperature and high strain rate superplasticity of the electrodeposited $\mathrm{Ni} /$ Si3N4(W) composite. Scripta Materialia. 2005; 53(11): 1285-1290. doi:10.1016/j.scriptamat.2005.07.029.

116. Xia Y, Sasaki S, Murakami T, Nakano M, Shi L, Wang H. Ionic liquid lubrication of electrodeposited nickel- $\mathrm{Si}_{3} \mathrm{~N}_{4}$ composite coatings. Wear. 2007; 262(7-8): 765-771. doi:10.1016/j.wear.2006.06.015.

117. Srivastava M, William Grips VK, Rajam KS. Influence of Co on $\mathrm{Si}_{3} \mathrm{~N}_{4}$ incorporation in electrodeposited Ni. J Alloys Compounds. 2009; 469(1-2): 362-365. Doi: 10.1016/j.jallcom.2008.01.120.

118. Krishnaveni K, Sankara Narayanan TN, Seshadri SK. Electrodeposited $\mathrm{Ni}-\mathrm{B}-\mathrm{Si}_{3} \mathrm{~N}_{4}$ composite coating: Preparation and evaluation of its characteristic properties. J Alloys Comp. 2008; 466(1-2): 412-420. doi:10.1016/j.jallcom.2007.11.104.

119. Pompei E, Magagnin L, Lecis N, Cavallotti PL. Electrodeposition of nickel-BN composite coatings. Electrochim Acta. 2009; 54(9): 2571-2574. doi:10.1016/j.electacta.2008.06.034.

120. Shrestha NK, Sakurada K, Masuko M, Saji T. Composite coatings of nickel and ceramic particles prepared in two steps. Surf Coat Technol. 2001; 140 (2): 175-181. doi:10.1016/S0257-8972(01)01045-3.

121. Liu E-y, Gao Y-m, Wang W-z, hangX-l Z, Wang X, Yi G-w, et al. Effect of the Synergetic Action on Tribological Characteristics of Ni-Based Composites Containing Multiple-Lubricants. Tribol Lett. 2012; 47(3): 399-408.

122. Güler ES, Konca E, Karakaya I. Effect of Electrodeposition Parameters on the Current Density of Hydrogen Evolution Reaction in $\mathrm{Ni}$ and $\mathrm{Ni}$ MoS2 Composite Coatings. Int J Electrochem Sci. 2013; 8(4): 5496 -5505 .

123. Lee W-H, Tang S-C, Chung K-C. Effects of direct current and pulseplating on the co-deposition of nickel and nanometer diamond powder. Surf Coat Technol, 1999; 120-121: 607-611. doi:10.1016/ S0257-8972(99)00445-4.

124. Teh K-S, Lin L. MEMS sensor material based on polypyrrole-carbon nanotube nanocomposite: film deposition and characterization. J Micromech Microeng. 2005; 15(11): 2019-2027. doi:10.1088/0960$1317 / 15 / 11 / 005$

125. He X, Wang Y, Sun X, Huang L. Preparation and Investigation of NiDiamond Composite Coatings by Electrodeposition. Nanoscience and Nanotechnology Letters. 2012; 4(1): 48-52(5).

126. Yagodkina LM, Loginova ID, Savochkina IE. Electrochemical deposition, structure, and properties of nickel-diamond coatings. Russ J Appl Chem. 1997; 70(10): 1556-1560.

127. Pandey B, Pal PP, Bera S, Ray SK, Kar AK. Effect of nickel incorporation on microstructural and optical properties of electrodeposited diamond like carbon (DLC) thin films. Appl Surf Sci. 2012; 261: 789799. doi:10.1016/j.apsusc.2012.08.101.

128. Kumar CP, Venkatesha TV, Shabadi R. Preparation and corrosion behavior of $\mathrm{Ni}$ and $\mathrm{Ni}$-graphene composite coatings. Mater Res Bull. 2013; 48(4):1477-1483. doi:10.1016/j.materresbull.2012.12.064.

129. Kuang D, Xu L, Liu L, Hu W, Wu Y. Graphene-nickel composites. Appl Surf Sci. 2013; 273: 484-490. doi:10.1016/j.apsusc.2013.02.066.

130. Lapinski J, Pletcher D, Walsh FC. The electrodeposition of nickelgraphite composite layers. Surf Coat Technol. 2011; 205(21-22), 


\section{5-5209. doi:10.1016/j.surfcoat.2011.05.030}

131. Zhao H, Lui L, Hu W, Shen B. Friction and wear behavior of Nigraphite composites prepared by electroforming, Mater Des. 2007; 28(4): 1374-1378. doi:10.1016/j.matdes.2006.01.001.

132. Plumier F, Chassaing E, Terwagne G, Delhalle J, Mekhalif Z Electrolytic co-deposition of a nickel/fluorographite composite layer on polycrystalline copper. Appl Surf Sci. 2003; 212-213: 271278. doi:10.1016/S0169-4332(03)00112-0.

133. You Y-H, Gu C-D, Wang X-L, Tu J-P. Electrochemical preparation and characterization of Ni-PTFE composite coatings from a nonaqueous solution without additives. Int J Electrochem Sci. 2012; 7 (12): 12440 - 12455.

134. Wang F, Arai S, Endo M. Electrochemical preparation and characterization of nickel/ultra-dispersed ptfe composite films from aqueous solution. Mater Trans. 2004; 45(4): 1311-1316.

135. Shoeib M. Structure and properties of electrodeposited Ni-PTFE coatings. Corrosion Prevention \& Control. 2002; 49: 141-148.

136. Bercot P, Pena-Munoz E, Pagetti J. Electrolytic composite Ni-PTFE coatings: an adaptation of Guglielmi's model for the phenomena of incorporation. Surf Coat Technol. 2002; 157(2-3): 282-289. doi:10.1016/S0257-8972(02)00180-9.

137. Ibe T, Kiyokawa H, Chong YB.Electrodeposition and surface properties of nickel-PTFE composite film. Mater Sci Res Inter. 1998; $4 ; 148-152$.

138. Pushpavanam M, Arivalagan N, Srinivasan N. Electrodeposited NiPTFE dry lubricant coating. Plat Surf Fin. 1996; 83: 72-76.

139. Kaczmar JW, Pietrzak K, Wosiski W. The production and application of metal matrix composite materials. J mater proc technol. 2000 106(1-3): 58-67. doi:10.1016/S0924-0136(00)00639-7.

140. Saji T, Shrestha NK. Non-aqueous Composite Plating of Ni-Ceramic Particles Using Ethanol Bath and Anti-wear Performance of the Coating. Surf Coat Technol. 2004; 186(3): 444-449. doi:10.1016/j. surfcoat.2004.01.006

141. Bapu GR. Electrocodeposition and characterization of NickelTitanium carbide composites. Surf Coat Technol. 1994; 67: 105-110.

142. Karbasi M, Yazdian N, Vahidian A. Development of electroco-deposited Ni-TiC nano-particle reinforced nanocomposite coatings. Surf Coat Technol. 2012; 207: 587-593. doi: 10.1016/j. surfcoat.2012.07.083

143. Asadi A, Zandrahimi M, Ebrahimi-Kahrizsangi R, Saidi A, Seyedalangi SM. New procedure for electrochemical production of $\mathrm{Ni}-\mathrm{TiC}$ composite powder. Powder Metallurgy. 2010; 53: 47-50. Doi: 10.11 79/003258909X12502872942570.

144. Gupta PK, Tiwari AN, Arawal BK. Electrodeposition and mechanical properties of Nickel-Tungusten carbide cermets. Trans Jpn Int Met. 1982; 23: 320-327.

145. Surender M, Basu B, Balasubramaniam R. Wear characterization of electrodeposited Ni-WC composite coatings. Tribo Int. 2004; 37(9): 743-749. doi:10.1016/j.triboint.2004.04.003.

146. Stroumbouli M, Gyftou P, Pavlatou E A, Spyrellis N. Codeposition of ultrafine WC particles in Ni matrix composite electrocoatings. Surf Coat Technol. 2005; 195(2-3): 325-332. doi:10.1016/j. surfcoat.2004.06.034

147. Jugovic B, Stevanovic J, Maksimovic M. Electrochemically deposited $\mathrm{Ni}$ - WC composite coatings obtained under constant and pulsating current regimes. J Appl Electrochem. 2004; 34(2): 175-179.

148. Kodandarama L, Krishna M, Narasimha Murthy HN, Sharma SC. Development and Characterization of Electrocodeposited NickelBased Composites Coatings. Journal of Applied Electrochemistry. 2004; 34(2): 1 75-179. DOI: 10.1007/s11665-010-9820-0.

149. Dalfard VM. Effect of Particle Size of Tungsten Carbide on Weight Percent of Carbide in Ni-WC Nano-composite. Int J Electrochem Sci. 2012; 7: 3537

150. Zimmerman AF, Clark DG, Aust KT, Erb U. Pulse electrodeposition of $\mathrm{Ni}-\mathrm{SiC}$ nanocomposite. Mat Let. 2002; 52(1-2): 85-90. doi:10.1016/ S0167-577X(01)00371-8.

151. Vaezi MR, Sadrnezhaad SK, Nikzad L. Electrodeposition of Ni-SiC nano-composite coatings and evaluation of wear and corrosion resistance and electroplating characteristics. Colloids and Surfaces A: Physicochem. Eng. Aspects. 2008; (315): 176-182. doi:10.1016/j. colsurfa.2007.07.027.

152. Li J, Sun Y, Sun X, Qiao J. Mechanical and corrosion-resistance performance of electrodeposited titania-nickel nanocomposite coatings. Surf Coat Technol. 2005; 192(2-3): 331-335. doi:10.1016/j. surfcoat.2004.04.082.

153. Zhang Y, Peng X, Wang F. Mater Lett. 2004; (58): 1134.

154. Stankovic VD, Gojo M. Surf Coat Technol. 1996; (81): 225.

155. Kariapper AMJ, Foster J. Trans Inst Met Finish. 1974; (52): 87.

156. Dobosz I, Rudnik E, Burzynska L. Arch Metal Mater. 2011; (56): 665.

157. Hou KH, Ger MD, Wang LM, Ke ST. Wear. 2002; (253): 994

158. Lekka M, Lanzutti A, Casagrande A, deLeitenburg C, Bonora PL, Fedrizzi L. Room and high temperature wear behaviour of Ni matrix micro- and nano-SiC composite electrodeposits. Surf Coat Technol. 2012; 206(17): 3658-3665. doi:10.1016/j.surfcoat.2012.03.016.

159. Gülb H, Kılıc F, Uysal M, Aslana S, Alp A, Akbulut H. Effect of particle concentration on the structure and tribological properties of submicron particle $\mathrm{SiC}$ reinforced $\mathrm{Ni}$ metal matrix composite (MMC) coatings produced by electrodeposition. Appl Surf Sci. 2012; 258(10): 4260-4267.

160. Hu F, Chan KC. Electrocodeposition behavior of $\mathrm{Ni}-\mathrm{SiC}$ composite under different shaped waveforms. Appl Surf Sci. 2004; (233): 163171.

161. Shrestha NK, Kawai M, Saji T. Co-deposition of B4C particles and nickel under the influence of a redox-active surfactant and anti-wear property of the coatings. Surf Coat Technol. 2005; 200(7): 24142419. doi: 10.1016/j.surfcoat.2004.08.192.

162. Medeliene V. The influence of $\mathrm{B} 4 \mathrm{C}$ and $\mathrm{SiC}$ additions on the morphological, physical, chemical and corrosion properties of $\mathrm{Ni}$ coatings. Surf Coat Technol. 2002; 154(1): 104-111. doi: 10.1016/ S0257-8972(01)01703-0.

163. Jiang JB, Zhang L, Zhong QD, Zhou QY, Wang Y, Luo J. Preparation and characterisation of nickel-nano-B4C composite coatings. Surf Eng. 2012; 28(8): 612-619. doi: 10.1179/1743294412Y.0000000038.

164. Riedel R. Novel ultra hard materials, Adv, Mater. 1990; (6): 549-560.

165. Deguchi T, Imai K, Matsu H, Iwasaki M, Tada H, Ito S. Rapid electroplating of photocatalytically highly active $\mathrm{TiO} 2-\mathrm{Zn}$ nanocomposite films on steel. J Materials Sci. 2001; 36(19): 47234729 . 
166. Keijser ThHDe, Langford JI, Mittemeijer EJ, Vogels ABP. Use of voigt function in a single line method for the analysis of $\mathrm{x}$-ray diffraction line broadening. J Appl Cryst. 1982; (15): 308-314. doi: 10.1107/ S0021889882012035.

167. Langford JI. A rapid method for analysing the breadths of diffraction and spectral lines using the Voigt function. J Appl Cryst. 1978; (11): 10-14. doi: $10.1107 /$ S0021889878012601.

168. Spanou S, Pavlatou EA, Spyrellis N. Ni/nano-TiO2 composite electrodeposits: Textural and structural modifications. Electrochim Acta. 2009; 54(9): 2547-2555. doi:10.1016/j.electacta.2008.06.068

169. Lekka M, Koumoulis D, Kouloumbi N, Bonora PL. Mechanical and anticorrosive properties of copper matrix micro- and nanocomposite coatings. Electrochim Acta. 2009; 54(9): 2540-2546. doi:10.1016/j.electacta.2008.04.060.

170. Goldstein AN, Echer CM, Alivisatos AP. Melting in semiconductor nanocrystals. Science. 1992; (256): 1425. doi: 10.1126/ science.256.5062.1425.

171. Cao G, "Nanostructures and Nanomaterials: Synthesis, properties and application. 2009.

172. Akhtar F, Askari SJ, Shah KA, Du X, Guo Shi. Microstructure, mechanical properties,electrical conductivity and wear behavior of high volume $\mathrm{TiC}$ reinforced $\mathrm{Cu}$-matrix composites. Composites Material Charecterization. 2009; 60(4): 327-336. doi: 10.1016/j. matchar.2008.09.014.

173. Erler F, Jacobs C, Romanus H, Spiess L, Wielage B, Lampke T. Interface behaviour in nickel composite coatings with nano-particles of oxidic ceramic. Electrochim Acta. 2003; 48(20-22): 3063.

174. Gomes A, da Silva Pereira MI, Mendonça MH, Costa FM. J Solid State Electrochem. 2005; 9: 190.

175. McCormack AG, Pomeroy MJ, Cunnane VJ. J Electrochem Soc. 2003; 150: C356.

176. Wang SC, Wei WCJ. Kinetics of electroplating process of nano-sized ceramic particle/Ni composite. Mat Chem Phys. 2003; 78(3): 574580. PII: S0254-0584(01)00564-8.

177. Tu WY, Xu BS, Dong SY, Wang HD, Bin J. Chemical and electrocatalytical interaction: influence of non-electroactive ceramic nanoparticles on nickel electrodeposition and composite coating. J. Mater. Sci. 2008; 43(3), 1102-1108.
178. Ding XM, Merk N, Ilschner B. Mechanical behaviour of metal matrix composite deposits. J Mat Sci. 1998; 33(3): 803-809.

179. Maurin G, Lavanant A. Electrodeposition of nickel-silicon carbide composite coatings on a rotating disc electrode. J Appl Electrochem. 1995; 25(12): 1113-1121.

180. Shao I, Vereecken PM, Cammarata RC, Searson PC. Kinetics of particle codeposition of nanocomposites. J Electrochem Soc. 2002; (149): C610-C614. doi: 10.1149/1.1514672.

181. Bund A, Thiemig D. Influence of bath composition and $\mathrm{pH}$ on the electrocodeposition of alumina nanoparticles and nickel. Surf Coat Technol. 2007; (201): 7092-7099. doi:10.1016/j. surfcoat.2007.01.010.

182. Ferkel H, Müller B, Riehemann W. Electrodeposition of particlestrengthened nickel films. Mater Sci Eng A. 1997; (234-236): 474476. doi: 10.1016/S0921-5093(97)00266-9.

183. Du L, Xu B, Dong S, Yang H, Wu Y. Preparation, microstructure and tribological properties of nano-Al203/Ni brush plated composite coatings. Surf Coat Tech. 2005; 192(2-3): 311-316.

184. Angadi MA, Udachan LA. Electrical properties of thin nickel films. Thin Solid Films. 1981; 79(2): 149-153.

185. Argibay N, Goeke RS, Dugger MT, Rodriguez MA, Michael JR, Prasad SV. Electrical resistivity of Au-ZnO nanocomposite films. J Appl Phys. 2013; 113(14): 1437121-1437126.

186. Chang SY, Chen CF, Lin SJ, Kattamis TZ. Electrical resistivity of metal matrix composites. Acta Materialia. 2003; 51(20): 6191- 02. doi: 10.1016/S1359-6454(03)00462-2.

187. Arsenault RJ, Shi N. Dislocation generation due to differences between the coefficients of thermal expansion. Mater Sci Eng A. 1986; 81: 175-87. doi: 10.1016/0025-5416(86)90261-2.

188. De Vrie JWC. Temperature-dependent resistivity measurements on polycrystalline SiO2-covered thin nickel films. Thin Solid Films. 1987; 150(2-3): 209-15. doi: 10.1016/0040-6090(87)90092-7.

189. Xiu ZY, Wu GH, Zhang Q, Song MH, Tian SF. Microstructure and electric properties of Sip/Al composites for electronic packaging applications Transaction of Non-ferrous Metals society of China. 2007; (17): 1034-1039. 